\title{
Black Sea-Caspian Steppe: Outline of Ethnic and Political Relations to the End of the Ninth Century
}

\subsection{Era of the Dominance of Iranian Nomads}

The accounts described in the previous chapter, despite having been written in various epochs by authors from different cultures, display a high degree of uniformity in their descriptions of the natural environment of the Black Sea and Caspian steppe. In these accounts we find explicit and implicit expressions of the belief that this region constituted an ideal natural habitat for nomadic peoples. According to available sources, pastoral communities have dominated the steppe since the dawn of history. It was on the Pontic steppe, for example, that the ancients placed the home of the Galaktophagoi (milk eaters) and the Hippemolgoi (mare milkers), ${ }^{1}$ whom they identified as Cimmerians, ${ }^{2}$ a people mentioned in the Odyssey. It is difficult to say whether this identification is correct. If the Cimmerians had indeed established settlements on the Black Sea steppe at that time, they would be the first nomadic group known (i.e., identified by name) to have inhabited this region. ${ }^{3}$ At present, however, there is controversy surrounding the group's link to archaeological remains of the Chernogorivka and Novocherkassk cultures (1oth-7th centuries BCE), whose people inhabited vast stretches of the Black Sea-Caspian steppe. Some scholars associate these cultures with a separate group of Iranian nomads, said to have been forerunners of the Agathyrsi, who are mentioned by Herodotus. ${ }^{4}$ Others believe that the Cimmerians may have never settled as far west as the Black Sea steppe, ${ }^{5}$ and question the credibility of claims, most often based on Herodotus' account in Histories, that they inhabited this region. ${ }^{6}$

1 Hom.Il. XIII 5-6 (p. 1).

2 Hom.Od. XI $15^{-20}$ (pp. 123-4). The Cimmerians were said to milk mares by Callimachus of Cyerene (Hymn III (to Artemis), verses 252-254: Call., 82, 83), which, according to some researchers, is supposed to prove their identification by the Hellenic poet with Homer's Hippemolgoi. Cf. Chochorowski 1993, 10. Other ancient authors identified the Hippemolgoi and the Galaktophagoi with the Scythians. Cf. Fr.Hes. 150; Strabo vil 3.7 (pp. 196-198), 3.9 (pp. 204-208).

3 Chochorowski 1993, 10; Harmatta 1970, 7-8; Czeglédy 1983, 28.

4 Olbrycht 2000a, 102-105.

5 Olbrycht 20oo, 71-99.

6 Hdt. IV 11-12 (pp. 210-213).

(C) ALEKSANDER PAROŃ AND INSTITUTE OF ARCHAEOLOGY AND ETHNOLOGY POLISH ACADEMY OF SCIENCES, 2021 | DOI:10.1163/9789004441095_004

This is an open access chapter distributed under the terms of the CC BY-NC-ND 4telicense. Paroń - 9789004441095 
The first clashes between the Cimmerians and Scythians took place when the first group still inhabited lands on what Herodotus calls the 'southern sea, identifiable as the Caspian Sea. These conflicts, most likely the result of migratory pressures, triggered a further wave of resettlement in the region. The defeated Cimmerians were driven from the lands they inhabited, with some resettling in the South Caucasus. By the end of the 8th century BCE, the Cimmerians had developed an active presence in West Asia, with settlements most likely having been established earlier on the Kura River (in today's southern Georgia). From these areas, they regularly carried out raids that filled the inhabitants of the Middle East with fear. ${ }^{7}$

The Cimmerians are known from Assyrian diplomatic sources as the Gimirrai, and are referred to in the prophecies of Ezekiel as the Gomer people. ${ }^{8}$ Around 715 BCE Rusa I, the ruler of the Urartu state, attempted to wipe them out. A battle that took place near Cappadocia (Kappadokía) ended in victory for the Cimmerians. ${ }^{9}$ Assyrian documents mention the Gimirrai again around 68 o BCE, when they fought against Assyria alongside the Medes. This alliance ended badly for the Cimmerians, whose forces were defeated by Esarhaddon in ca. 677 BCE. Some of their fighters then passed into the service of the Assyrian ruler, while others fought under Midas, King of Phrygia, though they later shifted their allegiance and joined the side of the Urartian king Rusa II. ${ }^{10}$ We read about the Cimmerians once again when they join forces with the Treri, a Thracian tribe, around 66o вСE in an attack on Lydia in Asia Minor. The Lydian King Gyges was killed in combat (ca. 654 BCE), and was succeeded by his son Ardys, who rebuilt the kingdom and pushed back the Cimmerians, who suffered a definitive defeat at the hands of the Assyrian king Ashurbanipal in $637 / 636$ вСЕ, after which they ceased to be a threat. They settled in isolated groups in Asia Minor, where they were eventually assimilated into other groups. ${ }^{11}$

The defeat of the Cimmerians, however, did not necessarily mark the end of the history of this South Caucasian tribe. In fact, whether they maintained a continued presence on the Black Sea steppe remains an open question. It is generally assumed today that they first appeared on the steppe at the beginning of the first millennium все. ${ }^{12}$ Their area of settlement overlapped the

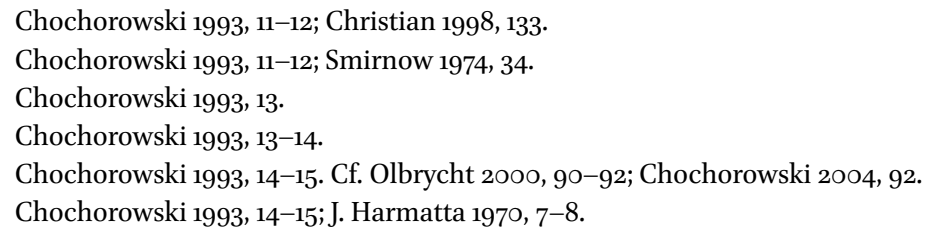


territories later inhabited by the Scythians, i.e., the region situated between the Don, Lower Danube, and the Carpathian Mountains. ${ }^{13}$ Important questions remain unanswered about the nature of their presence on these lands. Did the Cimmerians inhabit the northern Pontic Steppe or did they merely exert political control over this area? If we accept the latter view, it can be assumed that the Cimmerians were based at some point in the North Caucasus, which also explains their activity in West Asia. Some groups may have been forced by Scythian migration in the first half of the 7 th century BCE to migrate to the Black Sea steppe, while others lived in isolated communities in the South Caucasus. ${ }^{14}$

The migration of the Scythians was probably part of a larger wave of ethnic displacements. We can infer this from the accounts of Herodotus, who writes in the mid-5th century BCE that the Arimaspoi, a people living in the far reaches of the ecumene known to the Greeks (beyond them lived griffins who guarded treasures of gold), attacked the Issedones and forced them from their homes, which led the latter to do the same to the Scythians, who then seized the lands of the Cimmerians. ${ }^{15}$ However, Herodotus had earlier written that the cause of the Scythians' migration was the Massagetae, who drove them away from the Araxes River (Syr-Darya or Volga). ${ }^{16}$ The contradiction here is reconciled by Henryk Łowmiański, who claims the Issedones were attacking the Scythians from the north, while the Massagetae blocked their path to the south. ${ }^{17}$ In describing the struggle between these two peoples, Herodotus stated that during the Scythians' pursuit of the Cimmerians, the Scythians lost their way and marched along the northern and eastern ridge of the Caucasus into Media, where they defeated its inhabitants and gained control of West Asia. The Scythians' short rule (28 years) proved extremely harsh for the entire region. The Scythians plundered both Syria and Palestine, and one of their invasions even reached the borders of Egypt. ${ }^{18}$ Some of the information from Herodotus' Histories appears to be worthy of trust. The Scythians were known in Assyrian and Babylonian sources as the Iškuzai/Ašguzi. ${ }^{19}$ In addition, their presence

\footnotetext{
13 Chochorowski 1993, 10.

14 Chochorowski 1993, 14.

15 Hdt. IV 13 (pp. 212-215).

16 Hdt. IV 11 (pp. 210, 211).

17 Łowmiański 1975d, 104.

18 Hdt. I 15 (pp. 18. 19), 103-106 (pp. 132-139), 130 (pp. 168-171), IV 1 (pp. 198, 199).

19 Chochorowski 1993, 11; Łowmiański 1975d, 102; Melyukova 1990, 99, 435-440 (bibliography of the most important works); Christian 1998, 133-134.
} 
in West Asia and the Caucasus is confirmed by archaeological evidence. ${ }^{20}$ However, it is questionable as to whether their expansion in this region can be explained by their pursuit of the Cimmerians. The latter, as we have seen above, appeared in the South Caucasus (Transcaucasia) several decades before the Scythians, and moreover, the period of the supposed Scythian domination of West Asia falls in the last quarter of the seventh century все, ${ }^{21}$ when the Middle East was inhabited by rich and highly developed societies, whose wealth was likely to draw steppe-dwellers and their raids. The prospect of attaining such rich booty was sufficient motivation for the Scythians' expansion in the region. Their presence may therefore not have taken the form of permanent control over the region, but rather an extended period of looting expeditions. ${ }^{22}$

Scythian domination of the Black Sea steppe therefore begins in the mid-7th century BCE. Ethnically, the Scythians, like their predecessors, the Cimmerians, and their successors, the Sarmatians, were Iranian peoples. ${ }^{23}$ Until the end of the 7 th century вСЕ, these people played an important political role throughout West Asia. Their military presence in the region came to an end at the hands of Cyaxares, the king of the Medes. ${ }^{24}$ The remnants of the Scythian army returned to the Black Sea steppe no later than the early 6th century вСE. Here, according to the accounts of Herodotus, the nomads had to fight their own rebellious slaves. ${ }^{25}$ Perhaps this story, in which folk tale elements predominate, is a distant echo of some real uprising by the Scythians' subjects, ${ }^{26}$ as the nomads had indeed subjugated numerous settled communities. This state of affairs appears to be confirmed most clearly by the ethnonyms of the Scythian tribes provided by Herodotus. These seem to indicate that the western part of 'Old Scythia' was inhabited by agricultural communities: Scythian-tillers, Scythian-farmers, the Alazones, and the Callippidae. ${ }^{27}$ In the case of the

20 The long presence of the Scythians in the northern Caucasus is supposedly evidenced by their invasions in West Asia, which lasted throughout the 7 th century вCE. Their contacts with the North Caucasus ended only in the fifth century. Murzin 1979, 20; Vinogradov 1972, 234; Il'inskaia, Terenozhkin, 1983, 14, 19, 33, 77; Harmatta 199o, 123-127; Makhortykh 1991, 102-111.

21 Harmatta 1990, 119-120; Chochorowski 1993, 11.

22 Ivantchik 1999, 497-520 (He questions the fact that the Scythians attained political dominance over West Asia, although he assumes their military presence in the region). Cf. Murzin 2005, 34.

23 Melyukova 1990, 99; Kretschmer 1921, 923-926.

24 Melyukova 1990, 100; Harmatta 1990, 119-120; Chochorowski 1993, 15.

25 Hdt. IV1 (pp. 198, 199), 3-4 (pp. 200-203).

26 Melyukova 1990, 100. Cf. Ivantchik (1999, 506).

27 Hdt. IV 17 (pp. 216-219). 
last two tribes, Herodotus adds that they were Hellenic Scythians, i.e., most probably closely integrated with the Greek population. Apart from the tribes mentioned above, the inhabitants of Scythia also included nomad Scythians and Royal Scythians. According to Herodotus, the latter group dominated, and considered the other Scythians to be their slaves. ${ }^{28}$ From Royal Scythians most likely arose a triad of rulers who led all Scythian ethnos. A political organism of this type was credited with withstanding an invasion by Darius, the ruler of Persia, in ca. $513-512$ BCE. ${ }^{29}$

During the period of their domination on the Pontic steppe, the Scythians most likely maintained good contacts with the Greeks. This does not mean, however, that there were no tensions between the two sides. ${ }^{30}$ In general, however, the nomads' interest in trade with the Greek colonies on the Black Sea and Sea of Azov in all certainly required them to keep their bellicosity in check. ${ }^{31}$ From the Scythians, the Hellenes mainly purchased grain, for which there was a great demand in Greece. Another object of trade were Scythian slaves, whose presence in cities such as Athens is confirmed extensively in Greek literature of the classical era ( 5 th -4 th century вСE).$^{32}$ It cannot be ruled out that the Hellenes also purchased traditional nomadic products (milk, animal skins, horses, cattle, etc.). ${ }^{33}$ Among the Scythians, and among many other nomadic peoples, luxury goods produced in Greek craftsmen's workshops were highly prized. Judging by the content of the graves of the Scythian aristocracy, articles produced by Greek goldsmiths were particularly popular. ${ }^{34}$ The Steppe-dwellers also took advantage of the fact that an important trade route

28 Hdt. IV 19-20 (pp. 218-221).

29 Hdt. IV 1 (p. 198, 199), 83-93 (p. 284-295); 97-98 (p. 298-301); 118-142 (p. 316-343). Many researchers share the opinion that this expedition is a historic fact: Smirnow 1974, 102-105; Melyukova 1990, 101; Christian 1998, 135. However, since the end of the 19th century there have been a number of critical voices: Bury 1897; Harmatta 1990, 128-129; Łowmiański 1963, 121-122; Nenci 1958, 147; How, Wells 1912, 430-433; Hartog 1988, 191-226; Asheri, Lloyd, Corcella 2007, 573-574, 649-65o, 661-669.

30 What is particularly interesting is the rather positive, though not idealized image of the Scythians in Herodotus. This may have been a consequence of his perspective as a historian from Halicarnassus and of his focus on describing events in world history. In the everlasting war between East and West, the Scythians, as enemies of the Persians, like the Greeks, belonged to the latter faction. And from within such a broad perspective of history, smaller conflicts were probably not mentioned. Cf. Paron 2012, 79. The existence of short-lived tensions in relations between the inhabitants of the steppe and the Greeks seems, however, almost certain. Vinogradov 2008, 15.

31 On Greek-Scythian economic relations: Christian 1998, 152-155.

32 Jacob 1928, 53-78; Hall 1989, 138-139.

33 Melyukova 1990, 105.

34 Kubczak 1978, 76-125, 140; Melyukova 199o, 105. 
connecting the Black Sea coast with Inner Asia ran through their territory. The Scythians benefited greatly from the trade in goods. Archaeological sources indicate that the nomadic aristocracy was most affluent in the 4th century вСЕ. This was the period to which the most opulent and most numerous archaeological finds attributed to the Scythians are dated. ${ }^{35}$

Both constant contact with Greek culture and the influx of great wealth must have brought significant changes to the socio-cultural and political life of the steppe-dwellers. The strong influence of Hellenistic culture in the 6th and 5 th century в Ве is confirmed by Herodotus. ${ }^{36}$ Relatively early on, there was a fascination with Greek culture among Scythian elites. More widespread cultural change is noticeable among the Scythians at the end of the 5th century BCE, when an intensifying process of sedentarization can be observed among some nomadic groups. They settled mainly in eastern Crimea and the Taman peninsula, later on the Lower Dnieper, at the mouth of the Dniester, and finally (from the 4 th to the early 3 rd century вСE) in the Don Delta. ${ }^{37}$ Despite these changes, nomads still dominated in terms of numbers. Their expansion even reached the forest steppe zone, as demonstrated by barrows discovered in the Kiev region dating back to the 4 th and 3 rd centuries BCE. ${ }^{38}$

According to many scholars, manifestations of power, expressed mainly through the consumption of luxury goods and special funeral rites (in particular, barrows from the 4th century ВСЕ) testify to the Scythians' creation of state structures. ${ }^{39}$ Greek and Latin sources credit the Scythian king Atheas with creating this steppe empire, which stretched from the Don to the Lower Danube. ${ }^{40}$ However, in 339 вСE he was killed at the age of 9o in a battle with the Macedonian King Philip II, who took as spoils 20,000 captives (women and children) and enormous herds of cattle and horses. This battle took place in the Lower Danube region. ${ }^{41}$ This fact, along with the nature of the spoils that fell to Philip, is said by some scholars to prove that the Scythians were

35 Khazanov 1975, 240; 1978b, 429; Melyukova 199o, 101, 105; Murzin 2005, 34-35; Olbrycht 2000a, 109.

36 Hdt. IV 76, 78-8o (pp. 274-283). The stories of Anacharsis and the Scythian King Skyles, who died at the hands of their own brothers for their cultural apostasy.

37 Khazanov 1975, 239; Melyukova 1990, 104; Christian 1998, 155.

38 Khazanov 1975, 240; Kubczak 1978, 107-125; Melyukova 1990, 104.

39 Khazanov 1975, 218f.; 1978b, 427 (According to Khazanov, the so-called First Scythian State had already been established during the period of the alleged domination of nomads over West Asia. The Second Scythian State was created on the Black Sea steppe); Melyukova 1990, 105; Smirnow 1974, 109; Christian 1998, 149-152.

40 Khazanov 1975, 238-246; 1978b, 429.

41 Ius.-Trog. IX 2 (pp. 6o-61); Strabo VII 3.18 (p. 226). Cf. Khazanov 1975, 245; Christian 1998, 136; Murzin 2005, 38. 
then in retreat from the Sarmatians, who were attacking them from the east. ${ }^{42}$ This leads to the question: Did the death of Atheas lead to the breakup of the Scythian state? Those researchers who believe that his death did not lead to its sudden fall would appear to be correct. The fact that the Scythians later defeated Zopyrion, one of Alexander the Great's commanders, in the Siege of Olbia, testifies to their still considerable strength. ${ }^{43}$ Yet the Scythians' military activity in the Lower Danube area does indeed raise questions. In 313 BCE, they invaded the lands south of the Ister, but were beaten back. ${ }^{44}$ Not long afterward (309 ВСЕ), they were engaged in fighting in the Bosporan Kingdom. ${ }^{45}$ Both of these areas were very close to the territories over which the Scythians continued to maintain control. It thus seems that the final disintegration of the Scythian empire on the Black Sea steppe can be tentatively dated to the turn of the 4th and 3 rd centuries BCE. The cause of its demise - simultaneous pressures from Thracian and Celtic tribes to the west, and the Sarmatians to the east. ${ }^{46}$

Following the fall of Great Scythia, in its place there arose two new political organisms, known collectively as the Lesser Scythias. The first was created in the area of modern-day Dobrudja by a group of Scythians who settled on the right bank of the Danube and remained there until the ist century все. ${ }^{47}$ The second inhabited the mountainous and steppe regions of Crimea. During its height, its rulers also controlled the lands of the Lower Boh and Dnieper. This time of prosperity falls in the latter half of the 2nd century вСЕ, when the Lesser Scythia in Crimea was ruled by Skilurus. The Greek colonies recognized his sovereignty, a fact reflected in their minting of coins bearing the Scythian ruler's likeness. Skilurus held control over all of north-west Crimea. The main source of his vast wealth was trade, which was now being carried on without the Greek cities acting as intermediaries. During the reign of Palacus, the son and successor of Skilurus, Crimean Scythia declined in importance. This was mainly due to the intervention of Mithridates vi Eupator, King of Pontus. His involvement in this region was welcomed by the Black Sea Greeks, who hoped to free themselves from the burdensome tutelage of the Scythians. An invasion led by one of Mithridates' military commanders, Diophantus, brought about the final defeat of Scythians and ended their control of the Greek colonies, although the Scythian kingdom in Crimea survived until the invasion of

\footnotetext{
42 Harmatta 1970, 16.

43 Ius.-Trog. XII 1 (p. 78). Cf. Harmatta 1970, 17; Melyukova 1990, 106.

44 Diod. xix 73.4 (pp. 35, 36). Cf. Olbrycht 2oooa, 118.

45 Diod. Xx 24 (pp. 206-207).

46 Khazanov 1975, 245-6; Melyukova 1990, 107; Olbrycht 20ooa, 118.

47 Khazanov 1975, 247-8; Melyukova 1990, 107.
} 
the Goths, i.e., until ca. 23o. The final disappearance of the Taurian Scythians occurred during the Migration Period (Völkerwanderung)..$^{48}$

The abandonment by many nomads of the natural environment of the steppe resulted over time in changes in their lifestyle and means of support. In their late period (2nd century в $\mathrm{CE}-3$ rd century CE), the Scythians became a settled people. Their rulers did, however, make efforts to maintain their old traditions, traces of which can be found in the royal burial sites discovered in Scythian Neapolis. ${ }^{49}$

The Sarmatians became the political heirs of the Scythians. A series of events at the turn of the 4th and 3rd centuries BCE began a period of domination of the Black Sea steppe by this new group of Iranian tribes. Unlike the Scythians, the group described by ancient authors as the Sauromatians or Sarmatians was not a homogeneous political organism, but rather a collection of tribes that migrated into the area in successive waves. From a cultural point of view, these tribes can be regarded as homogeneous in the context of their nomadic lifestyle; there were, however, significant differences among them. ${ }^{50}$ The Sarmatians, like the Scythians, are considered by some scholars to be descendants of the so-called 'Timber-grave' (Srubnaia) culture of the late Bronze Age. ${ }^{51}$ These researchers also tend to share the conviction that these two peoples were closely related. Such a view was expressed in ancient times, beginning with Herodotus. He cited a legend according to which the Sauromatians were said to be descendants of Scythian men and conquered Amazons whom they had pardoned. ${ }^{52}$ Their language was also close to Scythian, being an 'impure' form of it, because the Amazon wives of the young Scythians never managed to learn to speak the language of their husbands well. ${ }^{53}$ Their joining forces to repel Darius' invasion also points to friendly contacts existing between the Sarmatians and Scythians. ${ }^{54}$

However, some doubts are raised by the differences in the names used to refer to these people. In the case of older authors (Herodotus, Hippocrates) they appear under the name Sauromatians $\left(\sum \alpha v p o \mu \dot{\alpha} \tau \alpha \mathrm{l}\right)$. We hear about the Sarmatians $(\Sigma \alpha p \mu \dot{\alpha} \tau \alpha \mathrm{l})$ for the first time in the writings of the Greek historian

48 Khazanov 1975, 248-251; Melyukova 1990, 107-108; Smirnow 1974, 113-119; Harmatta 1970, 20-21, 23-24.

49 Melyukova 1990, 109-110.

50 Sulimirski 1970, 22-25; Christian 1998, 136-137.

$51 \quad$ Melyukova 1990, 99.

$5^{2}$ Hdt. IV 110-116 (pp. 308-317).

53 Hdt. IV 117 (pp. 316, 317).

54 Hdt. IV 119 (pp. 318, 319). 
Polybius, in his accounts of events dating back to 179 вСЕ. ${ }^{55}$ Later writers (Strabo) use both ethnonyms interchangeably or have a very vague idea of the relationship between them (Pliny the Elder). ${ }^{56}$ Thus, the question arises as to whether we are dealing with two, perhaps related, but nevertheless separate ethnic groups. The majority of modern researchers favour the recognition of both names as lections of the same ethnonym. The main argument for this is the names given to the Alani, which in Ptolemy's work has been preserved as Alaunoi ('A $\lambda \alpha \hat{v} v 0$ เ $).{ }^{57}$ The older ethnonym continued to be used in archaeology only as a conventional device for separating the early stage of the development of Sarmatian culture (the Sauromatic period, 7 th-4th century BCE) from later phases. ${ }^{58}$

Some researchers, however, go further, distinguishing two spheres of culture 'provisionally labelled Sarmatian'.59 The first encompassed the area between the Don and Volga, while the second area lay between Samara and the Ural mountains. The Don-Volga region is said to correspond to the nomadic settlement area of Herodotus' Sauromatians, whose relations with the Scythians were generally good. For this reason, when Sauromatian tribal groups began

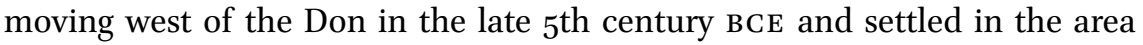
of the Maeotis, ${ }^{60}$ this migration did not cause a deterioration in the relations between these two peoples. ${ }^{61}$ Such a state of peace lasted until the expansion of the Samaran-Ural group, who, according to some researchers, comprised the bulk of the Sarmatians. ${ }^{62}$ Around the 4 th-3rd century BCE, a portion of the population of the southern Urals moved to the Lower Volga Region, conquering the Sauromatians living here. As a result, new 'Sarmatian' tribal groups formed, which in the 3 rd century BCE then began an invasion of the Black Sea steppe. ${ }^{63}$ These observations appear to be confirmed by information supplied by Diodorus Siculus, a writer from the ist century BCE, who claimed that the Sauromatians came to Europe from Media and settled to the east of the Maeotis and the Don. ${ }^{64}$ As the years passed, he says, their numbers grew (auksethentas - the use of this phrase may indicate that the population

\footnotetext{
55 Polyb. XXV 2.13 (p. 176). Cf. Łowmiański 1975b, 56; Harmatta 197o, 17-18, 43.

56 Plinius IV 8o (p. 178), VI 16 (p. 348), VI 19 (p. 35o). Cf. Łowmiański 1975b, 56.

57 Łowmiański 1975 b, 56 .

58 Łowmiański 1975b, 56 .

59 Melyukova 1990, 110.

6o Hippocr. XVII (p. 116). Cf. previous chapter.

61 Melyukova 1990, 111.

62 Melyukova 1990, 112.

63 Melyukova 1990, 112.

64 Diod. II 43.6 (pp. 28, 29).
} 
increased as a result of migration) and they ravaged large part of Scythia and turned most of the land into a desert. ${ }^{65}$ Some scholars have argued that archaeological data does not indicate that a direct link existed between the Sauromatians and the Sarmatians in the 3 rd century вСE. ${ }^{66}$ In light of such claims, it seems necessary to establish the exact relationship between these two ethnonyms. Even if the two peoples were closely related, this does not mean they should be identified as a single group.

Due to the scarcity and fragmentary nature of available sources, this chronology of Sarmatian-Scythian conflicts is somewhat speculative. Some researchers have expressed their conviction that the first clashes between these two peoples occurred as early as the 4 th century BСE. The above-mentioned actions of the Scythian king Atheas in the Lower Danube region were prompted by his loss of the eastern Black Sea steppe to the Sarmatians. His efforts were an attempt to compensate for the territories his people had lost and to acquire new lands from which to continue to defend themselves against incursions by the Sarmatians. ${ }^{67}$ However, the failure of Zopyrion's attack, as well as the rich artefacts found in Scythian burial mounds, most often dating back to the 4th century в СЕ, seem to indicate that in the last decades of that century the Scythian state still possessed considerable vitality. Its fall probably did not occur until the next century and, as noted above, was not brought about solely by the Sarmatians. The Scythians' migration was also a result of changes in the policies of the new Hellenic rulers of Iran towards steppe-dwellers in Central Asia at the end of the 4th century BCE. ${ }^{68}$ A series of nomadic invasions and subsequent retaliatory expeditions by the Seleucides are believed to have triggered ethnic displacements which led the Sarmatians to resettle in the North Caucasus area. The first mentions of their inhabiting the Black Sea steppe date back to the 3 rd century вСЕ. Valuable information is found in the so-called "Decree of Protogenes", an epigraphic source from Olbia. We learn from it that the inhabitants of the Greek colony were forced to pay tribute to Saitaphernes, ruler of the Saioi, usually identified with the Royal Sarmatians

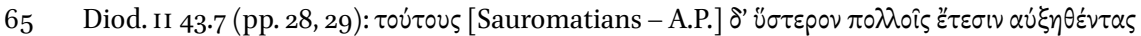

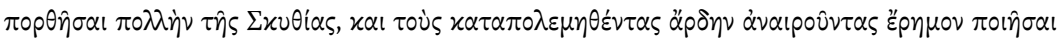

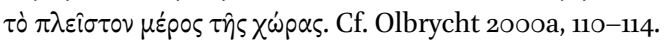

66 Melyukova 1990, 112.

67 Harmatta 1941, 52; 1970, 16; Sulimirski 1970, 101 (He claims that Atheas was not the ruler of all the Scythians, but only of the western elements that took refuge in Dobrudja).

Olbrycht 1979, 44; 2000a 118-119.
} 
described by Strabo. He mentions two other new peoples, considered by scholars to be Sarmatians: the Thyssamatae and Saudarmatae. ${ }^{69}$

In the 2nd century вСЕ, the Sarmatians were a significant force on the Black Sea steppe. This is evidenced by references to the Sarmatian king Gatalos in a peace treaty signed in $179 \mathrm{BCE}$ by Farnaces, King of Pontus, ${ }^{70}$ as well as an appeal by the Sarmatian queen Amage (ca. 165-140 BCE) to the Crimean Scythians to halt their attacks on Greek cities. ${ }^{71}$ All of these facts indicate that in the 3rd and 2nd century все a strong tribal confederation, led by the Royal Sarmatians, dominated the Black Sea steppe. This included the Iazyges, who lived along its western frontier, the Urgi, and the Roxolani, who inhabited the area between the Dnieper and the Don. ${ }^{72}$ This tribal confederation's control extended over the Black Sea steppe from the Danube to the Don. The Greek Pontic cities also fell under its authority for a time, until Mithridates VI Eupator, King of Pontus wrested control of them from the Sarmatians. This was followed by an agreement that led to a kind of political equilibrium. This alliance allowed the Sarmatians to begin expanding their political control over the Lower Danube area, where for a time they ruled over the Triballi. ${ }^{73}$

The death of Mithridates VI (63 в СE) and the disintegration of the Sarmatian confederation (ca. 61 BCE) led to the collapse of this political order. Greek Pontic cities came under Roman rule, while in the western part of the Black Sea steppe, the Dacians, headed by King Burebista, continued their expansion into the area. In ca. 50 BCE Burebista conquered and methodically weakened Olbia, which never regained its former glory. ${ }^{74}$ However, the changes described here did not signal the definitive fall of the Sarmatians, though some tribes did indeed disappear from history; this is especially true of the so-called Royal Sarmatians. Moreover, no supra-tribal Sarmatian political power would ever again come into being. The Iazyges and Roxolani, however, survived this period of weakness and re-established themselves around the close of the century. The first group resettled on the Lower Danube, and their attacks in this region are mentioned by Ovid (early ist century). ${ }^{75}$ Soon, however, the Iazyges migrated

\footnotetext{
69 IOSPE I 32 (pp. 43-56). Cf. Harmatta 1970, 10-12; Łowmiański 1975b, 57; Sulimirski 1970, 131-132; Olbrycht 2000a, 120; 2004, 333.

70 Polyb. XxV 2.13 (p. 176). Cf. Harmatta 1970, 19; Sulimirski 1970, 132-133; Olbrycht 20ooa, 121; 2004, 334 .

71 Harmatta 1970, 16-17; Sulimirski 1970, 135. Other researchers date Amage's intervention earlier, to 3rd century вСE: Rostovtzeff 1931, 16; Olbrycht 2000a, 120; 2004, 333.

72 Strabo VII 3.17 (pp. 220-222).

73 Harmatta 1970, 12-34, 39-40; Olbrycht 2004, 337-340.

74 Harmatta 1970, 29-31; Sulimirski 1970, 133-134.

75 Harmatta 1970, 41; Sulimirski 1970,134; Melyukova 1990, 113.
} 
onto the Hungarian Plain. Their path probably ran south through Oltenia and Banat. ${ }^{76}$ The Iazyges were persuaded to relocate their settlements by Roman diplomats, who used them to create a buffer zone between the territories of the empire and the warlike Dacians. ${ }^{77} \mathrm{~A}$ no less important reason for this shift, however, was the ethnic displacements taking place on the Caspian steppe in the early ist century. Acting as a rearguard for the Sarmatians were the Alani, who subjugated two Sarmatian tribes living between the Volga and the Don: the Aorsoi and the Siraces. ${ }^{78}$ The Roxolani, in turn, under pressure from the Siraces, filled the space left by the departure of the Iazyges. ${ }^{79}$ The most active group in the ist century, however, was the Alani, who terrorized the South Caucasus (Transcaucasia) and West Asia with their invasions. In $68 \mathrm{CE}$ their presence was also affirmed on the steppe of the northern Azov region. ${ }^{80}$ The Roxolani, who attacked the Danube provinces of the Roman Empire, were also highly active. ${ }^{81}$ In the late 2 nd century, they began to leave the Black Sea steppe, and migrated in a series of waves to the Hungarian Lowlands, where they brought the Iazyges under their control. The migration of the last Roxolani groups was probably accelerated by the arrival on the Pontic steppe of the Goths. ${ }^{82}$ This event marked the end of the Sarmatians' political domination in the western areas of this steppe. The eastern part (to the east of the Don) remained in the hands of the Alani, whose rule there ended with the arrival of the Huns. ${ }^{83}$ Some independent Alani groups remained in the Caucasus, ${ }^{84}$ while others travelled west to reach Gaul and Spain during the Great Migration, ${ }^{85}$ while still others chose to become subjects of the Huns. ${ }^{86}$

$76 \quad$ Harmatta 1970, 41.

77 Harmatta 1970, 42.

78 Harmatta 1970, 42; Sulimirski 1970, 142. The much more powerful Aorsi are sometimes associated with the An-ts'ai/Yen-ts'ai people, known to Chinese sources. Olbrycht 1998, 135; 2000a, 125. Another view is represented by K. Czeglédy $(1983,50-51,53)$, who identifies Yen-ts'ai with the Alani and believes that they originally belonged to the Aorsi federation, which controlled vast steppe areas from the Don to the lower reaches of the Syr Darya. After the fall of the Aorsi (around 5 O CE), the Alani assumed control of the federation.

79 Harmatta 1970, 48-49; Sulimirski 1970, 137, 139.

8o Harmatta 1970, 48-49 (The Alani did not reach the Danube in the 2nd century CE). Sulimirski 1970, 142-143; Melyukova 1990, 113; Olbrycht 2000a, 126-128.

81 Sulimirski 1970, 137 .

82 Harmatta 1970, 45-49; Sulimirski 1970, 167-168.

83 Sulimirski 1970, 162; Melyukova 1990, 113.

84 Sulimirski 1970,198-201; Melyukova 1990, 113.

85 Sulimirski 1970, 186-188.

86 Sulimirski 1970, 188-194. 
The Sarmatians, although related to the Scythians, never reached their level of development. Some researchers believe that they also failed to create their own state. ${ }^{87}$ Thanks to their control of the Black Sea steppe, Sarmatian tribal unions were able to develop trade relations with Greek cities on the coast of the Pontos, as well as with West Asia (mainly with Parthia). ${ }^{88}$ In the 1st century we can see a marked influx of Sarmatian immigrants from all social strata, including the aristocracy, into the cities on the northern coast of the Black Sea. ${ }^{89}$ The Sarmatians also actively participated in the political life of the Bosporan kingdom, founded at the beginning of the $5^{\text {th }}$ century вСЕ, backing a succession of candidates to the throne. ${ }^{90}$ The Sarmatians possessed strong cultural formation skills, as testified by their role in the development of the Cherniakhov and Saltovo-Maiaki cultures. ${ }^{91}$

\subsection{Gothic Episode}

As noted above, the 3rd century brought sweeping changes to the Black Sea steppe, as the political domination of Iranian nomadic groups in the region came to an end. The expansion of their successors, the Goths, into the area came from an unusual and thus surprising direction: the northwest. According to Jordanes, who wrote in the mid-6th century, they migrated from the legendary island of Skandza, ${ }^{92}$ which he called a "hive of races" and a "womb of nations". ${ }^{93}$ They were ruled by King Berig, who settled with his people in a region known as Gothiscandza ${ }^{94}$ According to some researchers who generally accept Jordanes' account, this region was located at the mouth of the Oder River. ${ }^{95}$ At some point, the Goths began a march through Pomerania toward the lower Vistula River, where Germanic settlement consolidated and stabilized. ${ }^{96}$ Their settlement of this area was supposedly noted by Claudius Ptolemy, who stated that the area south of the Vistula Veneti, on the right bank

\footnotetext{
87 Melyukova 1990, 116. For another opinion: Iatsenko 1993, 83-88; 2003, 88-99 (in terms of social and cultural development, the Sarmatians were almost equal to the Scythians).

88 Harmatta 1970, 34-39; Olbrycht 1998, 221-231.

89 Melyukova 1990, 115-116.

90 Sulimirski 1970, 123.

91 Sulimirski 1970, 170, 201-202.

92 'Insula magna, nomine Skandza'. Iord. 16 (p. 58).

93 '[...] Skandza insula quasi officina gentium aut certe velut vagina nationum [...]'. Iord. 25 (p. 6o).

94 Iord. $25^{-26}$ (p. 6o).

95 Strzelczyk 1984, 66; Kokowski 2008, 26-36.

96 Strzelczyk 1984, 66-67.
} 
of the lower Vistula, was the seat of the Gythones, ${ }^{97}$ whom most scholars identify as Goths. Material traces of their presence in this region includes sites of Wielbark culture. ${ }^{98}$

However, during the reign of King Filimer, the fifth successor to Bering, the decision was made to leave the ethnos' current area of settlement. According to Jordanes, this was due to overcrowding among the Goths. ${ }^{99}$ When Filimer reached Scythia, he established his rule over a land known as Oium, ${ }^{100}$ the name of which has been translated as 'meadow' or 'pasture' (German Aue). ${ }^{101}$ Archaeological data indicate that during the 2nd and 3 rd centuries, a closeknit group of peoples, distinct from those around them, migrated over time from the region of eastern Pomerania through Mazovia, Podolia, Volhynia and Ukraine towards the Black Sea. ${ }^{102}$ This migration is usually identified with what Jordanes called "the march of the Goths". ${ }^{103}$ However, the course of this journey was longer and more complicated than he imagined, and most likely spanned the reign of more than a single ruler.

Once the Goths reached the Black Sea steppe, they came into contact with the Sarmatian tribes who were the dominant force in the region. The Goth's territorial ambitions in Oium inevitably led to clashes with those living there. Scattered references to these battles are found in traditional sources. Jordanes states, for example, that the Goths first defeated the Spali (this is implied by the logic of his narrative), and then marched victoriously, occupying all of Scythia, until they reached the Pontic Sea. ${ }^{104}$ In reality, however, the course of events was certainly not as clear-cut as Jordanes claims. It is difficult to state with certainty when the first Goths reached the Black Sea steppe, when their migration into the area ended, or how these newcomers conquered and ruled over these lands. The terminus ante quem for their arrival is usually given as the date of the first Gothic invasion of the Roman Empire, i.e., the attack on Histria (Istros) at the mouth of the Danube in $238 \mathrm{CE}$. The Goths made this attack with the support of the Carpi, a Dacian people with whom they had formed a loose alliance. The Carpi withdrew their forces, however, after the Romans agreed

\footnotetext{
$97 \quad$ Kl.Ptol. III 5.20 (p. 304).

98 Strzelczyk 1984 66; Wolfram 199o, 50; Kokowski 2oo8, 39-67.

99 Iord. 26 (p. 6o).

100 Iordanes, 27 (p. 6o).

101 Zwolski 1984, 95; Łowmiański 1963, 261; Wolfram 1990, 52.

102 Strzelczyk 1984, 64; Heather 1996, 35-39.

103 Strzelczyk 1984, 66; Kokowski 2008, 71-97, 159-174.

104 Iord. 28 (pp. 6o-61).
} 
to pay them an annual tribute, leaving their discontented allies alone on the battlefield. ${ }^{05}$

There are no reports of further military activity by the Goths in the northern limes of the empire over the course of the next decade. The first group of Goths arrived in Scythia before $238 \mathrm{CE} .{ }^{106}$ It can logically be assumed that additional Gothic groups migrated to the Black Sea steppe over the course of the decade separating the two previously-mentioned attacks on Rome. ${ }^{107}$ During this period, the Goths completed their conquest of the region. The Greek colonies on the Black Sea coast (Tyras, Tanais) apparently held off their attacks somewhat longer, because they first began to serve as sea bases for further invasions only after ca. $25 \mathrm{O} \mathrm{CE}^{108}$ It is difficult to say which of the Sarmatian tribes were the first to be conquered by the Goths, and how seriously to treat Jordanes' references to the Spali. The existence of such an ethnos is confirmed by Pliny the Elder, who wrote in the ist century $\mathrm{CE}$, but he places them on the banks of the Maeotis. ${ }^{109}$ There is no way of knowing for certain whether they had still occupied settlements in the area in the first half of the 3 rd century CE. ${ }^{110}$ However, if this were the case, it would mean that the Goths began the conquest of their future homeland from its eastern edge, which is hard to imagine. It is also unclear why the Gothic tradition distinguishes this particular group, ${ }^{111}$ as it is very likely that all of the lands east of the Danube and west of the Maeotis and the Don were under the control of Gothic tribes.

Having imposed their rule on the peoples of Scythia, and most likely bolstered by waves of Germanic migration, the Goths resumed their attacks on the Roman Empire. Up until the mid-3rd century, their main area of penetration was the Danube provinces, ${ }^{112}$ but in the latter half of the century, a wave of Gothic invasions was aimed at securing lands along the Black Sea coast. These incursions were probably launched from port-towns of the former Bosporan Kingdom. Control of these ports, along with an alliance with

\footnotetext{
105 Łowmiański 1963, 264; Strzelczyk 1984, 59, 88; Kotula 1994, 71-72; Wolfram 199o, 54; Heather 1996, 40, 47 .

106 Strzelczyk 1984, 87; Kotula 1994, 71. Goths' incursions may have led to an earlier crisis and the fall of Olbia during the reign of Severus Alexander $(222-235 \mathrm{CE})$.

107 Łowmiański 1963, 264.

108 Strzelczyk 1984, 87, 90; Wolfram 1990, 58-59; Kotula 1994, 77.

109 Plinius Vi 22 (p. 352).

110 Some researchers tended to locate the Spali to the west of the Don (Łowmiański 1963, 26o), or between the Don and the middle Dnieper (Sulimirski 1970, 163).

111 Herwig Wolfram $(1990,53)$ states that their name in Slavic means 'giants', which is a common term for outsiders.

112 Strzelczyk 1984, 88-9o; Wolfram 1990, 54-58; Heather 1996, 40.
} 
the local population (the Borani tribe, based along the coast of the Maeotis, was noted to have taken part in one of the first invasions) allowed the Goths to transport their forces and launch attacks by sea. ${ }^{113}$ Their invasions reached ever more distant shores on the Black Sea. After an initial unsuccessful attack on the city of Pithyus ( $255 \mathrm{CE}$ ) in the western Caucasus, a succession of attacks gradually penetrated ever further along the eastern and southern shores of the Pontos Euxeinos (Black Sea), ultimately reaching the waters of the Propontis (today's Sea of Marmara). The next target of the Goths' attacks were cities of Bithynia (257 CE). ${ }^{114}$ Fierce attacks by the Goths and other allied peoples continued between 260 and 269 . In 267, the Herules (Heruli), perhaps assisted by the Goths, crossed the Propontis and sailed with a fleet of 500 ships into the Aegean Sea to attack Greece. Athens, Sparta, Argos, Corinth and Olympia were all taken and plundered. ${ }^{115}$ However, an unsuccessful invasion in 269 and further military defeats at the hands of Rome ${ }^{116}$ led to a sharp decline in attacks by Goths on the cities of the Mediterranean world. The year 270 marked a reversal of the Goths' fortunes. They were defeated by the forces of Claudius Gothicus and his successor Aurelian. This marked the beginning of a period of peace on the empire's Danube border that lasted for a century with only intermittent interruptions. Some scholars are inclined to assume that the conciliatory attitude of the Goths at this time was also due to upheavals taking place within the ethnos itself. According to Herwig Wolfram, a combination of events, including defeats in battles with the Romans and the evacuation of Roman Dacia ordered by Aurelian, severely tested the unity of the Goths and accelerated the process of their splitting into the Visigoths (Tervingi) and Ostrogoths (Greuthungi).117 There were already two distinct Gothic sub-groups in the year 291, when the Romans first noted the existence of two Gothic ethne. ${ }^{118}$ The Ostrogoths, the dominant group of the two, were credited with defeating the Alani and Urugundi on the Don basin. As inhabitants of the Black Sea steppe, the Ostrogoths are also the group of primary interest to us, though the history of this people, who lived farther away from the borders of the Roman Empire,

\footnotetext{
113 Strzelczyk 1984, 90-91; Wolfram 199o, 58-59; Kokowski 2008, 165-166.

114 Strzelczyk 1984, 90-91; Wolfram 1990, 59-61; Heather 1996, 40-41.

115 Strzelczyk 1984, 92; Wolfram 1990, 62-63; Heather 1996, 41. The last two authors date this expedition to the spring of 268 . Cf. Kotula 1994, 79-85.

116 Still in 268, the Goths suffered a significant defeat in the Battle at the Nessos River (on the border of Thrace and Macedonia). The following year, they suffered a devastating defeat to Claudius II Gothicus on the Naissus (today the Niš). Kotula 1994, 85-112; Strzelczyk 1984, 92-94; Wolfram 199o, 64-65; Heather 1996, 41.

117 Wolfram 199o, 65-66. Cf. Strzelczyk 1984, 94-95.

118 Strzelczyk 1984, 95; Wolfram 1990, 67.
} 
is less well known than that of the Visigoths. We know for certain that power within the group was held by the Amali royal family. They created what Herwig Wolfram describes as a military kingdom, unlike the Visigoths, among whom power rested with an aristocratic oligarchy. ${ }^{119}$

The Goths' conquest of the Black Sea steppe brought the region's ethnically diverse population under their rule; they thereby replaced Iranian nomadic groups - i.e., Sarmatian and Sarmato-Scythian tribes - as the dominant force on the steppe. ${ }^{120}$ A political system headed by the Amal clan was created in the area controlled by the Greuthungi. It was physically manifested in the rise of Cherniakhov culture, a highly developed culture that was dominant throughout the steppe and forest steppe regions, and extended in some places to forested areas. The peoples living within its borders supported themselves primarily from farming and cattle breeding. Its artisans produced high-quality handicrafts, including metalwork in both iron and non-ferrous metals, and specialized in the production of pottery and glass. It should be noted that despite the Goths' political dominance, Iranian groups played a significant role in the formation of the Cherniakhov culture, as did Geto-Dacian in its western extremes. ${ }^{121} \mathrm{~A}$ process of 'Scythianization' can even be seen among the Greuthungi, especially in spheres related to the art of war. Following the example of the Sarmatians, the Ostrogoths are said to have created mounted units armed with lances and swords. ${ }^{122}$ These forces could cover large distances easily, which helped the Amali to maintain order among the peoples under their rule. In addition to its steppe elements, the influences of provincial Roman settlements are also clearly visible in Cherniakhov culture. ${ }^{123}$ These cultural influences, especially those of the peoples living within the Ostrogothic Kingdom, were conducive to the formation of a distinct ethnic amalgam. The material benefits derived from incursions against the Roman Empire and the peoples of the northern Black Sea steppe further strengthened this process. The invasion of the Huns can thus be seen as interrupting the formation of a new ethnic culture. ${ }^{124}$

This Goth-dominated political structure's period of greatest splendour came under Ermanaric (Ermanaricus), 'the noblest of the Amali', ${ }^{125}$ whose reign

\footnotetext{
119 Strzelczyk 1984, 68; Wolfram 1990, 95, 123.

120 Szymański 1973, 27; Sulimirski 1970, 170.

121 Szymański 1973, 26-27; Sulimirski 1970, 170; Magomedov 2001, 113-132; Kokowski 2008, 199-217.

122 Wolfram 1990, 123; Kotula 1994, 68.

123 Szymański 1973, 27; Kokowski 2008, 199 .

124 Strzelczyk 1984, 61; Magomedov 2001, 140-147.

125 'Hermanaricus nobilissimus Amalorum'. Iord, 116 (p. 88).
} 
dates back to the mid-4th century. ${ }^{126}$ According to Ammianus Marcellinus, Ermanaric was 'dreaded by the neighbouring nations because of his many and varied deeds of valour'127 Additional information comes from Jordanes, who claimed that through his conquests he came to rule all the peoples of Germania and Scythia. ${ }^{128}$ He says the first victims of his conquests were 13 ethne: the Golthescytha, Thiudos, Inaunxis, Vasinabroncae, Merens, Mordens, Imniscaris, Rogas, Tadzans, Athaul, Navego, Bubegenas, Coldas. ${ }^{129}$ The identification of these groups remains under discussion today. The first two peoples are usually mentioned in combination and described as: 'the golden peoples of the Urals', with the suffix scytha- being considered a gloss by a later copyist. ${ }^{130}$ Somewhere in this vicinity lived the Imniscaris. The Vasinabroncae were the 'inhabitants of a flat country with lush grass, rich waters and swamps'. The next two ethnonyms probably refer to the Mari and Mordvins, Finno-Ugric tribes that inhabited the Volga region in the Middle Ages. The Imniscaris (In Old Rus' Mescera means 'beekeepers') belonged to the same ethnic group. The next two names, when merged, give *Roastadjans, i.e., 'inhabitants of the Volga coast'. This was most likely a group living on the river's left bank, opposite the Mordvins. ${ }^{131}$ There remains uncertainty as to the identity of the last four ethnonyms. ${ }^{132}$ Later victims of Ermanaric's expansion included the Herules, who lived on the Maeotis; the Venedas, a large but not particularly warlike Slavic group; and finally the Aests (Aesti), who inhabited the coast of the Germanic Ocean (Baltic Sea). ${ }^{133}$ The military successes described by Jordanes indicate that the lands under the rule of the Ostrogoth king stretched across the European continent from the Black Sea in the south to the Baltic Sea in the north, and from the Dniester and Vistula Rivers in the west to the Oka, Volga

\footnotetext{
126 Szymański 1973, 27; Strzelczyk 1984, 68; Magomedov 2001, 141-143.

127 Amm.Marc. Xxxi 3.1 (pp. 394, 396).

128 '...] idem ipse prudentia et virtute subregit omnibusque Scythiae et Germaniae nationibus ac si propriis lavoribus imperavit'. Iord. 120 (p. 89).

129 Iord. $116-117$ (p. 88).

130 Wolfram 1990, 96. Other possible interpretations are offered by Jerzy Strzelczyk (1984, 70). The Golthescytha were hypothesized to be the Goliad', a Baltic people who lived on the upper Oka in the early Middle Ages. The Thiudos were supposed to a term for the Chud, an ancient Rus' name for Finnish tribes.

131 Strzelczyk 1984, 69, 71; Wolfram 1990, 96.

132 The Finnish scholar Jooseppi Mikkola has suggested that peoples from the Rogas to the end of Jordanes' list should be located on the foothills of the Caucasus. His reasoning was based on an old Armenian geography by Movses Khorenatsi (8th century). Mikkola also suggests (probably correctly) that Ermanaric conquered well-developed areas (Kulturgegenden), which were located along major trade routes. Mikkola 1922, 56-66; Łowmiański 1963, 399-400 (critical on Mikkola's findings); Strzelczyk 1984, 71.

133 Iord. $117-120$ (p. 88-89).
} 
River basin and Urals in the east. It is hard to believe that Ermanaric was able to create such a vast, unified political organization. Some of the ethne under his rule inhabited lands two thousand kilometers from the Goths' core settlements. Scholars have justifiably concluded that Ermanaric's 'empire' can be divided into two parts. The first was a core area, limited to the lands inhabited by people of the Cherniakhov culture. The second consisted of lands under the Amali king's protectorate. ${ }^{134}$ These lands included important trade routes used since early antiquity as a link between the Mediterranean, the Baltic Sea region and Central Asia, which in part explains the Ostrogoths' motives for seeking to control them. ${ }^{135}$ The political system created by 'the noblest of the Amali' resembled the Pax Chazarica four centuries later, ${ }^{136}$ which had at its centre a strong and well-organized state (the Khazar Khaganate), to which numerous tribes pledged their allegiance. One of the reasons that this Khazar 'empire' was established was to protect and control the key trade routes that ran along the Volga River. This both provided the Khazars with guaranteed revenue from trade and allowed them to develop a rational, organized system for exploiting the resources of the region's inhabitants. It cannot be ruled out that Ermanaric, was also interested in moving beyond plundering and securing a steady source of income from trade. However, the political system he created covered an area much larger than that of the Khazars. Its vast scale is confirmed by the active contacts maintained between the Black Sea Goths and the peoples living within the Baltic Sea zone ${ }^{137}$ and in the Mediterranean area. The relatively long presence of the Ostrogoths on the Black Sea steppe provided them with a good understanding of the region's political and economic importance and its links with the interior of the continent. In addition, defeats in battles with Rome in the late 260 os and early 270 s and the subsequent disintegration of a unified Gothic political structure ultimately determined the direction of the Greuthungi expansion. While Ermanaric is traditionally considered the creator of this Ostrogoth 'empire', it cannot be ruled out that his predecessors had

\footnotetext{
134 Wolfram 1990, 96-97.

135 Wolfram 1990, 96. The fact that the Goths occupied an area of such great trade importance is widely accepted: Skarzhinskaia 196o, 266 (note 367); Łowmiański 1963, 40o-401; Strzelczyk 1984, 74-75. However, the possible consequences of this fact are interpreted in various ways. Skarzhinskaia believes that the Goths maintained purely commercial relations with the people on Jordanes' list. Henryk Łowmiański assumes that trade was also accompanied by Gothic invasions, though these did not result in the imposition of political control. Jerzy Strzelczyk hypothesizes there existed some form of tributary or militarypolitical dependence (forced alliances).

136 The author of this term, although he uses it in a slightly different sense, is Ananiasz Zajączkowski (1947, p. 77).

137 Urbańczyk 2000, 115.
} 
expressed similar aspirations. However, he was the one who managed to fully realize these intentions and to give the primitive raiding attacks of his forebears a more purposeful and rational form. ${ }^{138}$

\subsection{Period of Dominance of Turkic Nomads}

The political structure Ermanaric created proved to be quite fragile. Its collapse was brought about by the arrival of a new hegemon on the Black Sea steppe: the Turkic Huns. Their migration is of major importance to the history of Europe, especially its south-eastern regions. I am thinking here not only about the Huns initiating the 'migration of peoples', which was to contribute to the collapse of the Western Roman Empire, but also to a number of important political and ethnic shifts that affected the entire Eurasia steppe, from the Volga River basin to the Hungarian plain. At the end of the 4th century, this area fell under the political domination of Turkic peoples, who gradually replaced the Indo-European groups living there. ${ }^{139}$ Turkic nomads enjoyed a long, uninterrupted period of political supremacy on the Black Sea and Caspian steppe that only ended with the arrival of the Mongols in the 13th century.

Despite the great importance of their migration, our knowledge about the Huns' original area of settlement is limited. According to Ammianus Marcellinus' Res gestae, the Huns originally inhabited areas stretching from the Maeotic Sea to the Glacial Ocean. ${ }^{140}$ Similar information can be found in Jordanes' account. ${ }^{141}$ On the basis of these descriptions, little can be said about the Huns' geographical homelands. It is also difficult to determine how far to the east their nomadic settlements reached. In Ammianus Marcellinus' account, there is a tendency to locate the Huns at the borders of the ecumene, a suitable place for a people said to 'exceed every degree of savagery'.142 We know even less about the origins of this tribe. Ammianus states that little was known by his predecessors about the Huns. Zosimos of Panopolis offers a stereotypical genealogy, ascribing Scythian origins to them, while Jordanes provides a legendary origo, according to which the Huns were descendants of the offspring of evil spirits and witches (the Halirunnae) who had been sent into exile by King Filimer. ${ }^{143}$ This information does not allow us to say anything

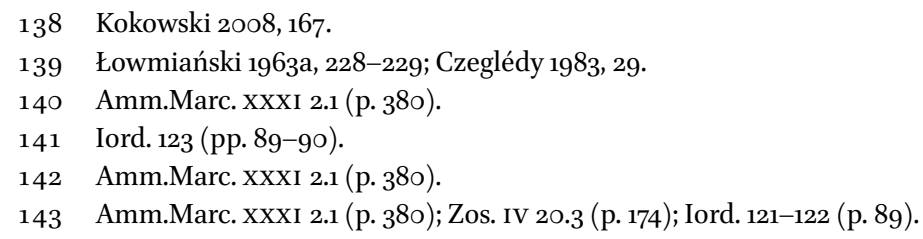


certain about the ethnogenesis of this people, but it clearly shows how great a shock their arrival created in the Mediterranean world. ${ }^{144}$

The findings of modern researchers do not provide much new information. In the eighteenth century, the French orientalist Joseph De Guignes hypothesized that a link existed between the so-called 'European Huns' and the Xiongnu (Hsiung-nu) people, ${ }^{145}$ who created a strong steppe empire near China and for many centuries posed a serious problem for their neighbours. ${ }^{146}$ However, during a period of crisis in the Xiongnu state early in the Common Era, part of this ethnic group migrated to the west. ${ }^{147}$ The European Huns are said to have later emerged from these peoples. This traditional concept has long been and continues to be accepted by many scholars, ${ }^{148}$ but numerous researchers have doubts about this explanation. It cannot be ruled out that some groups of Xiongnu survived the collapse of their state, and joined the ranks of the European Huns after moving westwards. However, it is extremely difficult to prove this was indeed the case because there are no clear references to either of these two peoples during the period between the collapse of the Xiongnu state and the arrival of the Huns in Europe. ${ }^{149}$

The first victims of the Huns were the Alani, who lived on the Don. They were most likely conquered early in the 370 . ${ }^{150}$ Following this victory, the Huns turned to the Kingdom of Ermanaric. Despite his initial efforts to challenge their invasion, the aging ruler was unable to halt the aggressors and committed suicide. ${ }^{151}$ It is very likely that the arrival of the Huns unleashed tensions within Ermanaric's multi-ethnic state. It is strongly suggested by Jordanes' account of events during this period ${ }^{152}$ that such tensions contributed significantly to the collapse of the monarch and his political system. Ermanaric's successor,

\footnotetext{
144 On the origo of the Huns: Maenchen-Helfen 1944a, 244-251; Tyszkiewicz 2001, 81-90.

145 Guignes 1756, 215-218.

146 Dąbrowski 1975, 29-35; Jagchid, Symons 199o, 24-36, 52-67, 114-120, 141-144, 165-170; Di Cosmo 2002; Barfield 1992, 32-84.

147 Dąbrowski 1975, 35.

148 Hirth 1899, 245-278; Gumilev 1966; Cf. Łowmiański 1963a, 229 (n. 704); Czeglédy 1983, 33; Tyszkiewicz 2004, 11-32; Kliashtornyi, Savinov 2005, 33, 35; Botalov 2009, 32; Hyun Jin Kim 2013, 26-31.

149 Maenchen-Helfen 1944, 222-243 (for a systematic analysis of the arguments in favour of such an identification of both peoples); 1973, 444-455; Sinor 1990, 178-179; Yu Taishan 2014, 233-264 (he analyzes the arguments justifying the identification of both peoples in order to conclude that the identity of the Huns and Xiongnu cannot be proven on the basis of these arguments). Cf. Łowmiański 1963a, 229-23o.

150 Amm.Marc. Xxxi 3.1 (pp. 394, 396). Cf. Maenchen-Helfen 1973, 19-23; Dąbrowski 1975, 43; Sinor 1990, 180 .

$15^{1}$ Amm.Marc. XXXI 3.2 (p. 396).

$15^{2}$ Iord. 129-130 (pp. 91-92). Cf. Maenchen-Helfen 1973, 21-22; Strzelczyk 1984, 77-78.
} 
Witimir, identified by Jordanes as Winitar (Vinitharius), fought to maintain his people's independence, but was eventually killed in battle by Balamber, ruler of the Huns. ${ }^{153}$ The Ostrogoths, like the Alani before them, were forced to submit to the rule of the invaders. They were now placed under the rule of Hunimund, a member of the Amali line and a vassal of the Huns. A group of Ostrogoths who refused to submit to the rule of the nomads left their people, and ultimately were given refuge in the Roman Empire. ${ }^{154}$ These events occurred in ca. 375. The Huns soon took control of the lands up to the Dniester River, where Athanaricus, iudex (i.e., 'judge', as opposed to rex) and leader of the Visigoths, tried to halt their further expansion. But after twice suffering defeats on the battlefield, his rule was challenged by his people. Most Visigoths sought refuge within the Roman Empire, while Athanaricus and his followers took control of Caucaland, ${ }^{155}$ an area usually located in the sources in either Transylvania ${ }^{156}$ or Banat. ${ }^{157}$ The influence of the Huns had now reached the Lower Danube, and soon contacts were established with Rome, which at the time was preoccupied with defending themselves from the Goths.

The organization of the Huns' society during this period is worthy of special attention. Available sources say very little on this subject, and much of what is written is fragmentary and based on stereotypes. Outside of Balamber, whose historicity is questioned by some researchers, ${ }^{158}$ we know none of the names of the Huns' rulers from the mid- to late-4th century. The names of the first chiefs are known only from an account describing events dating back to 395 . Such the case, it can be concluded that until the beginning of the $5^{\text {th century }}$ we cannot speak of the existence of a single ruler to whose authority all Hun groups submitted. Individual tribal units are believed to have enjoyed considerable independence, as evidenced by the ease with which they were able to shift their allegiance to Rome and acquire the status of foederati. ${ }^{159}$ Some scholars even suggest that there was no strong sense of solidarity or ethnic awareness among the Huns. It would seem, however, that a great deal of caution needs to be exercised in regard to such findings, due to the unreliability

\footnotetext{
153 Amm.Marc. XXXI 3.3 (p. 396); Iord. 246-249 (pp. 121-122). Cf. Maenchen-Helfen 1973, 22-23; Sinor 1990, 18 o.

154 Amm.Marc. XxXI 3.3 (p. 396); 12,12 (p. 468); Iord. 250 (p. 122). Cf. Maenchen-Helfen 1970, 26-27; Sinor 1990, 18 o.

155 Amm.Marc. XXXI 3.4-8 (pp. 396, 398, 40o); 4/12 (pp. 406, 408); Iord. 131-133 (p. 92).

${ }_{15} 6$ More precisely, in the Strâmba river valley (Hungarian: Tekerőpatak), which is a tributary of the Mureş river (Hungarian: Maros).

157 The area between the Mureş (Hungarian Maros), Tisza and Danube Rivers. MaenchenHelfen $1973,25^{-26 .}$

158 Thomson 1948,57 .

159 Sinor 1990, 181-182.
} 
of the sources at our disposal. Compared to the period analyzed here (very late 4th century), these sources are few in number and burdened with strong negative stereotypes. Their authors, even ones as outstanding as Ammianus Marcellinus, present the Huns as wild, lawless creatures, deprived of moral principles and growing out of a horse's body like a centaur. 160 'Though they live in the form of men, they have the cruelty of wild beasts', writes Jordanes. ${ }^{161}$ The Huns' alleged lack of leaders fits perfectly with the image of them as a horde of wild animals, devoid of leadership. On the other hand, it is hard to imagine that nomads capable of defeating theoretically better organized enemies (e.g., the Ostrogoths and Visigoths) would have fought without commanders.

The Huns' main settlements at the end of the 4th century were most likely located on the Black Sea steppe. This is indicated by their incursions deep into West Asia. In 395-396, the Huns launched a major invasion led by Basich and Kursich through the Caucasus into Armenia, Syria, Palestine, and northern Mesopotamia. The aim of this attack was apparently plunder, as evidenced by the fact that the invaders took large herds of cattle. ${ }^{162}$ The type of booty taken suggests that the Huns' invasion may have been prompted by hunger they were suffering on the Pontic steppe. ${ }^{163}$ In the west, nomadic groups controlled Pannonia, Wallachia, and Dobrudja. The lands of the latter became the starting point for attacks on Rome, which became widespread in the 5 th century. These were carried out by Uldis - the second Hun ruler (after Balamber) known to us by name - who is known to have invaded Thrace two times (404-405, 408). ${ }^{164}$ The purpose of these invasions was primarily plunder and there was no attempt by the Huns to instate their rule on lands belonging to the Empire.

In 412-413, Olympiodorus of Thebes was sent to the Huns on a diplomatic mission. Accounts of his work as an envoy have been preserved only in fragmentary forms. We do not know exactly who he represented. Some researchers believe he was an agent of Emperor Honorius and met with the Hun king Charaton in Pannonia. Others believe that he was sent by Theodosius II and that the meeting place was the Black Sea steppe. We also do not know the purpose of this mission. ${ }^{165}$

\footnotetext{
16o Amm.Marc. XXXI 2. 2-11 (pp. 38o, 382, 384, 386).

161 Iord. 128 (p. 91): Hi vero sub hominum figura vivunt beluina saevitia. English translation: Mierow 2007, 75 .

162 Prisc. 11.2 (pp. 276, 278) Cf. Maenchen-Helfen 1973, 51-59; Sinor 199o, 182. The expedition of Basich and Kursich to West Asia described by Priscos sometimes is dated back to 420430: Demougeot 1979, 517-518; Kazanski, Mastykova 2009, 123-124; Kazanski 2009, 85.

163 Maenchen-Helfen 1973, 52; Sinor 199o, 183.

164 Maenchen-Helfen 1973, 59-72; Sinor 1990, 184-185.

165 Maenchen-Helfen 1973, 73-74; Sinor 1990, 185-186.
} 
We hear about the Huns again in accounts of a major invasion in 422 during which they ravaged Thrace and reached the gates of Constantinople. Two kings, Roas (Rugila, Ruga) and his brother Octar, ruled jointly over the Huns. The people's political affairs were handled by Roas, who also led its military expeditions. He forced Theodosius II to sign a peace agreement which provided for payment by the Eastern Roman Empire of a tribute in the amount of $35^{\circ}$ pounds of gold a year. ${ }^{166}$ However, from the time of Roas to the 44os, the Huns' rulers continued to actively engage Byzantium along its Balkan border. As in the time of Uldis (Ulti), the nomads' military actions in the region were not aimed at territorial expansion. The objectives of both Roas and Octar and, later, Attila and Bleda, were limited to extracting ample tributes, demanding the extradition of fugitives who had taken refuge within the Empire, and selling back the Romans they held in captivity for a handsome sum. ${ }^{167}$

After a peace with the Western Roman Empire had been consolidated in $432 / 3$, the Huns made preparations for another invasion of the Byzantine Empire. The reason for this was said to be their desire to pacify certain tribes that the Hun ruler considered to be his subjects and which had taken refuge within the territory of the empire. The sudden death of Roas did not save Constantinople from danger, because his successors, Attila and Bleda, continued the political course set by their uncle. To maintain the peace, Byzantium was forced agree in 433 to double its annual tribute, pay amends for fugitives in its territory, and conclude a trade agreement with the Huns. ${ }^{168}$

For the next several years, there was peace in the Balkans. The nomads did not cross the empire's border, which ran along the Danube, even in the face of growing arrears in Constantinople's tribute payments. However, a new conflict, the exact course of which is unclear, erupted in 441 and ended in a severe defeat for the empire. ${ }^{169}$ The provisions of the peace agreement, dated 447 , were extremely harsh. Constantinople would now have to pay an annual tribute of 2,100 pounds of gold (six times as much as in 422), was obliged to immediately pay 6,ooo pounds in payments in arrears, once again pay amends for fugitives who had taken refuge in the empire, and finally, agree to withdraw from a strip of land south of the Danube five-day's travel in width. This 'demilitarized zone' was intended to allow for easy observation of the movements

166 Prisc. 2 (p. 224). Cf. Maenchen-Helfen 1973, 76, 81-94; Sinor 1990, 186-188.

167 The ransom increased in successive arrangements: in 433 it was 8 gold pieces, in 447-12 pieces per head. Prisc. 2 (p. 226), 9.3 (p. 236).

168 Prisc. 2 (pp. 224, 226). The agreement of 433 covers the equal treatment of Huns and Romans in marketplaces. Cf. Maenchen-Helfen 1973, 9o; Sinor 1990, 188.

169 Maenchen-Helfen 1973, 102-123. 
of military units and people in the area. ${ }^{170}$ It is difficult to say whether this last point of the agreement was ever carried out. The imminent death of Theodosius II (27 July 450) and a radical change in policy towards the Huns by his successor Marcian suggest that such a withdrawal never took place. ${ }^{171}$

At this time, we can also observe greater involvement by Attila in the West. His intentions now were much more ambitious and far-reaching, including winning the hand of Augusta Honoria, sister of Emperor Valentinian III, and with this marriage, attaining great influence in the Western Roman Empire. ${ }^{172}$ Attila invaded Gaul in 451, but his troops were defeated in the Battle of the Catalaunian Fields by a coalition of Roman and Visigoth armies. As a result of this defeat, Attila failed to achieve the main goal of the campaign, i.e., the destruction of the Roman legions in Gaul. ${ }^{173}$ However, this was not the beginning of the end for the Huns or for Attila. This was demonstrated the following year, when the Huns invaded northern Italy and plundered the cities of the Po Valley. This time, too, the invasion was not a complete success. According to tradition, Attila abandoned plans for a march on Rome after being persuaded to do so by Pope Leo I. Otto Maenchen-Helfen believes the primary reason for this decision was actually an epidemic that had begun to decimate the ranks of the barbarians. It also cannot be ruled out that Attila met with a determined defence that halted his advance at the foot of the Apennines. ${ }^{174}$

The sources we have at our disposal provide a much more palpable account of the history of the Huns' involvement in fighting in the Balkans and Western Europe. Yet for our purposes, much more important is their activity in the east of the Continent, with a particular emphasis on the Black Sea and Caspian steppe. Indeed, in Attila's time and even earlier, it cannot be ruled out that the centre of the Huns' lands was in the west. In the mid-5th century, this was the area between the Danube and Tisza (Tisa) Rivers. However, there is no reason to believe that the Huns gave up control of the Black Sea steppe during this period, ${ }^{175}$ as it remained a region of great strategic importance, and was

170 Prisc. 9.3 (p. 236), 11.1 (p. 242). Cf. Wirth 196o, 41-69; Maenchen-Helfen 1973, 124-125; Sinor 1990, 189-19o.

171 Sinor 1990, 192.

172 Prisc. 20.1 (pp. 304, 306), 20.3 (pp. 306, 308). Cf. Gračanin 2003, 62, 64-67; Tyszkiewicz 2004, 141-16o.

173 Maenchen-Helfen 1973, 129-131.

174 Maenchen-Helfen 1973, 132-141; Sinor 199o, 192-196.

175 According to Priscos of Panion, Attila 'ruled the islands of the Ocean and, in addition to the whole of Scythia, forced the Romans to pay tribute.' Whatever is meant by the second of the geographical concepts mentioned by the Byzantine diplomat, it seems that it probably covers significant stretches of the Eastern European steppe. Prisc. 11.2 (p. 276). On the possible meanings of the use of this phrase by Priscos: Paron 2006, 448, 450; 2013, 226. 
close to the heart of the lands they controlled. The Huns' interest in this area is demonstrated by incidents related to a failed diplomatic mission carried out by an unknown agent of Theodosius II to the Akatziri. Information about this mission, the aim of which was the forming of an alliance with the Akatziri, is found in the writings of Priscos of Panion. ${ }^{176}$ If Byzantium had been successful, it would have gained a very valuable ally, as the Akatziri inhabited areas to the rear of the Huns. Constantinople's plans, however, were never realized because one of the tribal chiefs, Kouridachus, reported the Byzantine plot. In 445 , a punitive expedition was launched against the tribes which had conspired with Constantinople. ${ }^{177}$ All of the Akatziri leaders, with the exception of Kouridachus, were placed under the rule of Ellac, Attila's eldest son. ${ }^{178}$

The death of Attila (453) and the Huns' defeat in the Battle of Nedao (454 or 455) resulted in a sudden disintegration of their empire. The nomads suffered huge losses, with nearly 30,000 warriors killed, including Ellac. ${ }^{179}$ Those who survived the slaughter withdrew under the command of Irnich to 'Lesser Scythia' (probably today's Dobrudja), while Ellac's place was taken by Dengizich. In 466, the brothers approached Emperor Leo I with a proposal for peace and a request to designate sites through which the Huns could trade with Byzantium. The Emperor's refusal infuriated Dengizich, who began preparations for renewed military action; Irnich, however, preferred a different path of action, and for a time conflict was avoided. ${ }^{180}$ But this calm did not last long. Three years later, Dengizich died in battle fighting the Romans in an effort to win the status of foederati for his people. The surviving nomads took refuge within the empire. ${ }^{181}$ At this point, we hear nothing more about Irnich and the Huns under his rule. The fact that his name is found second on a list of

Archaeological data also support similar conclusions. Remnants of material culture discovered in the area, ranging from the central Danube to the Ural Mountains and western Kazakhstan, show a number of similarities. Researchers, however, distinguish two separate regions, the border of which ran along the Dnieper River. The western region is said to have been inhabited by the Huns, while the eastern regions were inhabited by peoples subordinate to them. Kazanski, Mastykova 2009, 114-126; Kazanski 2009, 65-404.

176 Prisc. 11.2 (p. 258).

177 Maenchen-Helfen 1973, 103-105.

178 Sinor 1990, 190-191; Kazanski, Mastykova 2009, 124 (researchers locate Akatziri's dwellings on the Don and in the Crimea).

179 Iord. 262 (p. 125). Cf. Maenchen-Helfen 1973, 147-151; Sinor 1990, 197-198.

18 o Prisc. 46 (p. 352). Cf. Maenchen-Helfen 1973, 165-166 (believes that the settlements of Dengizich and his people were located in the area of today's Wallachia).

181 Prisc. 48 (p. 354). Cf. Maenchen-Helfen 1973, 166-168. 
Bulgar princes seems to indicate that his people may have survived and later become part of the Bulgar tribal union..$^{182}$

But was he able to maintain his hegemony on the Black Sea steppe? Probably not. Political changes were taking place in the region triggered by new migrations dating back to ca. 463. According to Priscos of Panion, the Black Sea steppe was invaded at that time by peoples of the Saragur, Ugor and Onogur tribes. These tribes were forced to leave by the Sabir people, who in turn were forced to migrate by the Avars, who were said to be fleeing from a horde of man-eating griffins (sic!). ${ }^{183}$ This last piece of information is most likely a topos borrowed from Herodotus by which the author tries to explain the reason for the Avars' migration, which he apparently does not know. ${ }^{184}$ The above-mentioned tribes are usually labelled together in scientific literature as Oghuric tribes; before their arrival on the Black Sea steppe, they probably lived in western Siberia and the steppe of Kazakhstan. Some researchers assume that they comprised the western part of a tribal union referred to by Chinese sources as T'ie-lê. ${ }^{185}$ Western Siberia, the Ili River valley and western Tien-Shan were the seat of the Sabirs. ${ }^{186}$ The expansion of the Avars, who forced the Sabirs to migrate, was probably the root cause of the defeat inflicted on them by China in $460 .{ }^{187}$ After arriving on the Black Sea steppe, the Oghurs quickly became the dominant force in the region. Initially, the dominant position was held by the Saragurs, who in 467 conquered the Akatziri and other unknown peoples. ${ }^{188}$ They soon attracted the attention of Byzantine diplomats. Having formed an alliance with Constantinople, the Saragurs directed their military forces against the Persian empire. ${ }^{189}$ Afterwards, however, there is no further mention of their name in the sources. ${ }^{190}$

The first mention of the Bulgars, who at that time were allied with Emperor Zenon against Theodoric, ruler of the Ostrogoths, dates back to 480. The ethnonym 'Bulgar', which is usually translated as 'mixed', was applied to various peoples, but predominately to Huns and Oghurs. Their area of activity in the coming centuries would range from the North Caucasus to the Lower

\footnotetext{
182 Sinor 1990, 198-199; Golden 1980, 43; 1990, 256-257.

183 Prisc. 40.1, 40.2 (p. 344).

184 Moravcsik 1930, 55-59.

185 Czeglédy 1983, 35-37, 100, 109-110; Golden 199o, 257.

186 Czeglédy 1983, 37, 100; Golden 1990, 257.

187 Golden 1990, 258.

188 Prisc. 40.1, 40.2 (p. 344).

189 Prisc. 47 (pp. 352, 354). Cf. Czeglédy 1983, 97-98; Romashov 1992-94, 218-19.

190 Moravcsik 1930, 59-62. The last mention of the Saragurs is made by Zacharias Rhetor (6th c.). Cf. Golden 199o, 258; Romashov 1992-94, 219 (the scholar assumes that their existence as an independent ethnos came to an end as the result of their defeat by the Turks).
} 
Danube. ${ }^{191}$ At the turn of the fifth/sixth century, strong ethne may have already existed here. The area east of the Dnieper and west of the Don, and perhaps as far as the lower Danube, was occupied by the Kutrigurs. Their neighbours to the east were the Utigurs, who lived between the Don and Kuban Rivers. The nomadic settlements of the Onogurs were located on the Kuban River itself. ${ }^{192}$ The relations between these tribal groups and Byzantium, especially those of the Kutrigurs, took various shapes. Periods of peace and cooperation were interwoven with invasions and armed confrontations. In 499 the Bulgars broke their alliance with Constantinople and began a series of invasions, which at intervals of several years plagued the Balkan provinces of Byzantium. In 517 they reached Thermopylae, and in 530 they ravaged Illyricum. ${ }^{193}$ In the same year, Kutrigur troops fought as an ally of the Empire in Italy. ${ }^{194}$ In the years 539-540 they once again became an enemy of Byzantium. During their invasions, which date back to the mid-sixth century $(551,559)$, they reached Constantinople and entered Greece and Asia Minor. Due to Justinian the Great's diplomatic efforts, a fratricidal war broke out between the Utigurs and Kutrigurs, which resulted in a short break in the Bulgars' attacks on Byzantium. ${ }^{195}$ The appearance of the Avars on the Black Sea steppe temporarily lessened the threat from the Bulgars. ${ }^{196}$

In the early years of the next century, another participant in the migration of 463 , the Sabirs, settled in the Volga region and the northern Caucasus, where they quickly became the dominant political force. In 508 , they devastated Armenia, and in later years, fought as an ally of Byzantium against Persia. ${ }^{197}$

At the turn of the fifth and sixth centuries, a rather short-lived balance of power emerged on the Black Sea and Caspian steppe. The western part of the region was controlled by Oghuric tribes, and the eastern part by the Sabirs. However, this political order broke down in the mid-6th century following the arrival of the Avars.

The relationship between these Avars and those mentioned in the accounts of Priscos of Panion is unclear. Until recently, both were generally identified as the same group, and it was assumed that the forerunner of this ethnos was

\footnotetext{
191 Beševliev 1981, 75; Romashov 1992-94, 205-208, Pohl 2008, 281-282; Ziemann 2007, 38-39, 44-45.

192 Romashov 1992-94, 209-217, 251; Wasilewski 1988, 32-33; Golden 199o, 258; Ziemann 2007, 95-103.

193 Beševliev 1981, 77-81; Wasilewski 1988, 33.

194 Golden 1980, 34-36; 1990, 258-259.

195 Syrbe 2012, 295-298.

196 Beševliev 1981, 95-101; Wasilewski 198o, 33.

197 Golden 199o, 259-26o.
} 
what is known in Chinese sources as the Rouran Confederation. ${ }^{198}$ In 551, an uprising against the Rouran broke out among the Göktürk people, who lived under their rule. They quickly brought down the state established by their former rulers and forced them to flee westward. As in the case of the Huns, however, the issue of their ethnogenesis is complicated. ${ }^{199}$ The main role in the formation of this nomadic group was probably not played by the defeated and discredited Rouran, although some aspects of their political organization were quite likely incorporated into that of the Avars.

In 557 or 558 , the Avars established contacts with Constantinople. ${ }^{200}$ They quickly brought the Sabirs, Alani, and all three Oghuric tribal unions under their rule. ${ }^{201}$ Their reign, however, proved to be rather short-lived, as in 567 the Avars were forced to moved on to Pannonia under pressure from newly-arrived Göktürks. ${ }^{202}$

Ultimately, in spite of resistance from the Onogurs and the Alani, the Göktürks had few problems bringing the steppe region under their control. ${ }^{203}$ The fact that Persia was a common enemy for both Byzantium and this new dominant power on the Black Sea steppe opened up opportunities for political cooperation between the two. However, the Byzantines' delay during a previously arranged joint campaign angered the Göktürks, who in retaliation attacked and occupied the Crimean Boporus. The expansion of nomadic groups also affected the northern Caucasus, where Abkhaz tribes, among others, were conquered. Hostility between Constantinople and the rulers of the Ashina clan continued up until the collapse of the Turkic Khaganate. ${ }^{204}$ The main reason for its downfall was a civil war fueled by China's Sui dynasty (584). In 6o4, the political unity of the khaganate was ultimately broken, and it splintered into two rival orders: eastern and western. The latter included territories to the west of the Dzungarian Basin. Continual internal conflicts led to the weakening of the Western Turkic Khaganate. However, the death blow was struck by the powerful Chinese Tang Dynasty, which until the end of the seventh century would maintain a weak, vassal khaganate in its place. ${ }^{205}$

\footnotetext{
198 Czeglédy 1983, 105, 106-107, 118.

199 Szymański 1979, 25-31; Pohl 1988, 278-281; Yu Taishan 2014a, 297-325.

200 Pohl 1988, 37-38; Golden 1990, 26o.

201 Pohl 1988, 39-40; Golden 1990, 26o.

202 Pohl 1988, 49-51; Golden 1990, 26 o.

203 Romashov 1992-94, 228-230; Golden 1990, 260.

204 Golden 1980, 38-39; 1990, 26o-261; Sinor 199oa, 304-305.

205 Gumilev 1993, 135-147, 154-16o; Golden 1980, 39; Sinor 1990a, 305-308; Romashov 199294, 231-2.
} 
The loosening of Turkic control over the Pontic-Caspian steppe, caused by the issues described above, led to changes in political relations within the region. On the one hand, there was a return of Avar influences, especially in the western part of the Black Sea steppe. At the turn of the 6th and ${ }^{7}$ th centuries, the Avar Khaganate was at the height of it power and posed a serious threat to Byzantium. ${ }^{206}$ Yet there was also a progressive strengthening of Oghuric tribes, the strongest of which turned out to be the Onogurs, whose settlements were on the Kuban River. The Onogurs took part in the T'ie-lê confederation's uprising against the Göktürks. ${ }^{207}$ They also sought to emancipate themselves from Avar influence. This last fact made them a natural ally of Byzantium. Friendly relations with Emperor Heraclius were maintained by Orkhan, the Onogur Khan. In 619 he arrived with his family and an extensive entourage to Constantinople, where he was baptized and received the rank of patrician from the Emperor. ${ }^{208}$ His nephew Kubrat, a member of the Dulo clan, was taken as a hostage to Byzantium, where he accepted Christianity. In 635, he defeated the Avars and renounced his allegiance to the Turks. During his reign, so-called Great Bulgaria was created, stretching from the Kuban to the Dnieper and including the tribal union of the Kutrigurs, who had previously been under Avar rule. Kubrat, like his predecessor, maintained friendly relations with Constantinople, whose support allowed him to create a vast political body. ${ }^{209}$ However, the hegemony of the Onogur Bulgars on the Black Sea steppe did not last long. By the mid-7th century disruptive forces began to show themselves. According to Byzantine sources, at the time of his death, Kubrat had five sons who, despite his father's admonitions, failed to maintain a united front, and divided their people instead. This state of affairs made them vulnerable to outside enemies like the Khazars, and around 66o, Great Bulgaria disintegrated under pressure from them. ${ }^{210}$ The various sons of Kubrat all reacted differently to the threat posed by the Khazars. The oldest son Batbaian $\left(\mathrm{B} \alpha \tau \beta \alpha \iota \hat{\alpha} v / \mathrm{B} \alpha \iota \alpha v_{o ́ s}\right)$ remained in his homeland and came to terms with Khazar

206 Szymański 1979, 32-41; Pohl 1988, 58-59, 128-162, 237-255; Kliashtornyi, Savinov 2005, 92-101.

207 Czeglédy 1983, 109-112; Golden 199o, 261.

208 Golden 1980, 44; Wasilewski 1988, 33.

209 Moravcsik 1930, 71; Wasilewski 1988, 33; Beševliev 1981, 145-148; Golden 198o, 44; 199o, 261-262; Romashov, 232-244; Kliashtornyi, Savinov 2005, 98.

210 Dunlop 1954, 41-43; Tryjarski 1975, 174-176; Beševliev 1981, 149-155; Wasilewski 1988, 33-34; Golden 1980, 44-45; 199o, 262; Romashov 1992-92, 249-250. The relationship between the fratricidal struggle between Kubrat's sons and the Khazar attack is unclear and has been a frequent topic of discussion. Recently, Veselina Vachkova (2008, 351 (n. 25) has described this issue as a typical academic problem. 


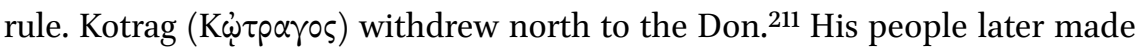
their way (no earlier than the mid-8th century) to the Volga in the environs of the Kama River Estuary, where a state known as the Volga-Kama Bulgaria

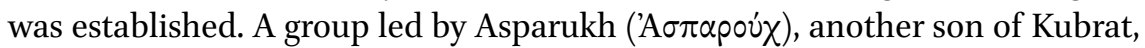
crossed the Dnieper River and settled on the lower Danube around 68o, giving rise to the First Bulgarian Empire. Finally, the last two unnamed sons, whose existence is often questioned by scholars, were to move to the westernmost lands with their peoples. One reached Pannonia, where he recognized the sovereignty of the Avars; the other travelled to Italy and settled near Ravenna. In this way, the legend attempts to explain the presence of Bulgar groups in Italy and Pannonia. ${ }^{212}$

In the latter half of the $7^{\text {th }}$ century, the rulers of the Khazar Khaganate became the new masters of the Black Sea and Caspian steppe. This political organism deserves a closer look for a number of reasons, the most important of which - its longevity and stability - are of exceptional importance in steppe conditions. Not much is known about its origins. It was most likely an amalgam of nomadic tribes (including Sabirs, Oghurs and Göktürks) headed by a charismatic Turkic family, which were the main elements contributing to the creation of the Khazar Khaganate. ${ }^{213}$ The early history of the Khazars is therefore very closely connected with the history of the Turkic Khaganate, and more specifically with the period of its domination in the western part of the Great Steppe. The Khazars emerged suddenly from the chaos that arose during the weakness and fall of the Western Ashinids and created a new khganate. Information about the Khazar language is scant and often contradictory. Arabic writers suggest it was similar to other Turkic languages, although they also emphasize its specificity. The few extant pieces of linguistic evidence seem to indicate a close affinity with what has been dubbed the 'common Turkic language', but, as Peter Golden states, there is no definitive proof of this. ${ }^{214}$ Between the $7^{\text {th }}$ to the mid-9th centuries, the Khazars' expansion spread across vast areas of the Black Sea and Caspian steppe, sporadically extending even beyond these borders. The Khaganate's influence stretched from the Kama River in the north to the Caucasus in the south, and from the Don and

211 This interpretation has been rejected by István Zimonyi, who rightly points out that in the Byzantine tradition descriptions of events associated with the break-up of 'Great Bulgaria' contain no mention of any group of refugees that supposedly reached the confluence of the Kama and the Volga. Zimonyi 199o, 62-63.

212 Moravcsik 1930, 71-73; Tryjaski 1975, 175-176, Golden 1990, 262-263.

213 Pletneva 1976, 14-23. Golden 1980, 58-59; 1990, 263; 2005, 57-59.

214 Golden 1980, 51-57; 1990, 263-264; Erdal 2005, 125-139 (He is highly sceptical of the assumptions made to date). 
Donets Rivers in the west to the Ural River in the east. Like the kingdom of the Goths in the 4th century, this political organism had a territorial core located in the region of the Volga estuary and the steppe of the North Caucasus. The remaining areas were Khazar protectorates. It cannot be ruled out that from at least the first half of the gth century the sovereignty of the Khaganate was recognized by the lands of East Slavdom, including Kiev. ${ }^{215}$

Such a vast and ethnically diverse organism was characterized by its strong vitality. Up until the mid-1oth century, the Khazar Khaganate was the strongest state in Eastern Europe, and the main force determining the political relations in the region. It was able both to effectively limit the migration of warlike nomads from the Transvolga Region and Inner Asia and to hold back Arab expansion. The Khazars created a political order with a high level of stability and security in the light of steppe conditions. Ananiasz Zajączkowski described it as the Pax Chazarica. ${ }^{216}$ The Polish scholar noted that it allowed for the creation of optimal conditions for the development of trade in the region, which was centred along the Volga River, ${ }^{217}$ with the Khaganate's last capital (Itil) lying on its delta near the Caspian Sea. ${ }^{218}$

Other forms of economic activity also expanded greatly in the Khazar state. This is indicated by archaeological remains of the Saltovo-Maiaki culture, which was centred in the basin formed by the Don, Donets and their tributaries. Remains of it have also been found in Dagestan, Eastern Crimea and on the Black Sea steppe. A slightly different variant of Saltovo-Maiaki culture has been also observed along the central Volga. It existed from the mid-8th to the 1oth century, and therefore corresponds to the period of splendour and gradual disintegration of the Khazar Khaganate. The creators of this archaeological culture are said to have been peoples from within the Khaganate, but its territorial range does not fully coincide with the that of the Khazar state. Based on a comparison of funeral rites, the closest archaeological match is between two groups under Khazar rule, the Bulgars and the Alani. The first of these peoples, who were based in the steppe north of the Sea of Azov, buried skeletal

215 Golden 1980, 86-88; 1990, 264; Pletneva 1976, 43-6o. According to an account by Ahmed ibn Fadlan from the first half of the 1oth century, the ruler of Khazaria collected tribute from 25 peoples whose leaders were likewise obliged to give him their daughters in marriage. ibn Fadlan-Yaqut: ibn Fadlan, 256/7. Cf. Dunlop 1954, 140-2.

216 Zajączkowski 1947, 77; Cf. Boba 1967, 226.

217 Nagrodzka-Majchrzyk 1975, 422-431.

218 On Khazar cities: Artamonov 1962, 178, 211, 219-220, 222-3, 234-5, 387-8, 398-9; Pletneva 1967; Nagrodzka-Majchrzyk 1978, 125-134; Romashov 2004, 189-264; Flerov 2011 (the researcher consistently proves that there were no Khazar cities. He even refuses to consider Itil a city); Zhivkov 2015, 196-212. 
remains in grave pits, while the latter, who lived somewhat further north in the forest-steppe zone, buried their dead in catacomb tombs. A significant part of the population of the Saltovo-Maiaki culture made a living from animal husbandry. Traces of yurts discovered by archaeologists testify to their connection to a nomadic lifestyle. However, remains of this culture have also been found in settlements and strongholds. We can thus observe a progressive process of sedentarization, with a large part of the population living a settled or semi-settled lifestyle, and engaging in activities typical of such a lifestyle. Land cultivation was also on an advanced level, as indicated by the agricultural tools discovered (ploughs with iron fittings, sickles). Gardens and vineyards were also cultivated, and hunting and fishing played an important role in the economy, as well, providing a source of additional income for both shepherds and farmers. Crafts were also well-developed, including smithing, goldsmithing, and pottery-making, which is unusual for nomads. Production of this kind flourished mainly in towns and strongholds. Yet among the settled population there were also signs of continued nomadic traditions. It is believed that some farmers left town each spring, and returned in autumn with their harvests. ${ }^{219}$

The diversity of the Khaganate's population in terms of material culture is accompanied by a diversity in terms of spiritual culture. This can best be seen in religious practices. With time, Judaism became the dominant religion, i.e., the religion practiced by the Khazar elites. It is difficult to determine the date of this conversion and the circumstances surrounding it. It most likely occurred over a period of time between $75^{\circ}$ and $850 .{ }^{220}$ The conversion of the elites, however, was not linked to persecution of believers of other religions. Evidence of tolerance towards dissenters is found in information preserved in al-Masudi's writings. Writing in the 1oth century, the Arab author mentions the appointment by the Khazar rulers of seven judges who were to pass sentences

219 Pletneva 1967, 144f.; 1999, 7-23; Hilczer-Kurnatowska 1975, 30-34; Noonan 1995-97 253-318; 2007 207-244. The last scholar believes that the highly diversified nature of the Khaganate's economy, i.e., the existence of such a wide range of economic activities, a diversity exceptional on the steppe, made the Khazar state particularly resilient. At the same time, he states that the main source of crisis within the state, and to a considerable extent, the reason for its downfall, was a decline in the importance of the Volga trade route in the late gth century. Thomas Noonan thus recognizes the crucial role of trade in the Khaganate's economy. A slightly more nuanced picture has been recently presented by Boris Zhivkov: 2015, 171-220.

220 Dunlop 1954, 85f.; Artamonov 1962, 264-29o; Pletneva 1976, 62; Golden 1983, 134-139; Petrukhin 2001, 111-113; Zuckerman 1995, 241-25o (he dates the conversion to Judaism to 861 or soon afterwards); Kovalev 2005, 220-253; L'vova 2005, 143-152 (the Russian scholar assumes that the first khagan to follow Judaism was Aibat (after 690-730/1). 
in accordance with the laws in force for a given religious group. Christians, Jews, and Muslims had two judges each, while pagans had one. ${ }^{221}$

The foreign policy of the Khazar rulers often involved entering into alliances with Byzantium, although relations between successive khagans and basileis were not always friendly. ${ }^{222}$ This cooperation between the two states dated back to 626, when the Khazars fought as allies of Emperor Heraclius in his campaigns against the Avars and Persians. ${ }^{223}$ The subsequent destruction of Great Bulgaria, also an ally of Byzantium, as well as competition for influence in the Crimea and South Caucasus certainly distanced the two states from each other. The main factor contributing to the improvement of Khazar-Byzantine relations seems to have been the threat from the Arabs. The Khazars had been fighting wars with them since 642 . Initially, this fighting did not bring much success to either side. In 737, a military breakthrough occurred that posed great dangers for the Khazars. The Arab leader and future caliph Marwan ben Muhammad successfully invaded the Lower Volga and occupied the heart of the Khaganate. The Khazar ruler was forced to fee and seek refuge in the territory of his vassals, the Burtas. The Khazars, wanting to preserve at least some of their people's cultural distinctiveness, recognized the sovereignty of the Caliph and adopted the Muslim religion. This forced conversion was soon renounced, and war once again broke out between the two sides. A conflict began that continued without resolution until the end of the 8th century. With time a lasting political balance was re-established in the Caucasus region. The city of Derbent (Bab al-Awab) marked the border of the two sides' spheres of influence. Yet, contrary to popular belief, the Khazars did not so much stop Arab expansion into the region as merely provoke conflicts with the Caliphate through their bellicose actions and attacks. ${ }^{224}$ However, this does not change the fact that their hostile attitude towards the Islamic world naturally brought them closer to Byzantium.

The role played by the Khazar Khaganate on the Black Sea steppe was a second argument for convincing Constantinople that friendly relations should be maintained. Thanks to the Khazars, from the middle of the seventh century to the end of the ninth century, we do not hear of any serious ethnic shifts in

221 Al-Masudi, 11; Pellat 1962, 162. Cf. Por. Dunlop 1954, 93, 206-207; Golden 199o, 266. For more on the subject of the Khaganate's ideological and religious syncretism: Zhivkov 2015, 17-126.

222 The existence of such a close relationship between the Khazars and Byzantium has been justifiably questioned by Noonan (1992, 109-132).

223 Golden 1980, 50-51; Gumilev 1993, 196-201.

224 Dunlop 1954, 45-87; Pletneva 1976, 35-42; Golden 1980, 59-65; 199o, 264-265; Wasserstein 2007, 373-386. 
the region of Black Sea-Caspian steppe. The only exception, dating back to the beginning of the second third of the 9 th century, was the migration of Magyars, which did not lead to any major political perturbations. Byzantine sources note the empire's role in helping to build the Sarkel fortress, situated on the Don. This suggests that the Khazars acted as a policeman, maintaining stability and the political balance on the Black Sea and Caspian steppe, and did so with the approval and support of Constantinople. ${ }^{225}$ Earlier marriages of the

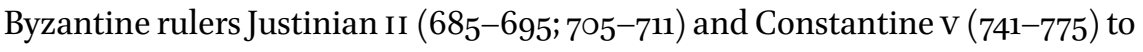
Khazar princesses provide an additional example illustrating the proximity of contacts between the two states. ${ }^{226}$

At the end of the gth century, the first signs of crisis in this efficient and stable political structure began to appear. The creation of a Rus' state and the shift of its centre to Kiev on the middle Dnieper triggered the process of freeing East Slavic tribes from their submission to the Khaganate. ${ }^{227}$ Thus, just beyond the borders of the Khazar state a dangerous and highly expansive rival appeared Kievian Rus' - that would ultimately contribute to its downfall. At the same time, ethnic shifts were taking place that initially must have been problematic for the Khazar monarchy. The Pechenegs were one of the main participants in these shifts.

They appeared on the Black Sea steppe during a period of profound change, which would eventually turn the steppe into a niche region, surrounded by powerful and stable monarchies of sedentary peoples. From the nomads' point of view these changes were not beneficial. The Black Sea steppe had previously been part of the Great Steppe politically, and events there determined mainly by ethnic shifts among its inhabitants themselves. The nomadic 'early states' created by the Scythians and Khazars proved to be more resistant to such disruptive changes. The secret of their relative success seems to have been their development of a more diversified economy and the ability to create links between the worlds of nomads and of settled farmers. This first skill gave them the ability to rationally exploit the agricultural population, which was subjected to the authority of the steppe rulers; the second allowed the nomads to fulfil the role of a commercial intermediary, establishing trade ties between the 'barbaric' North and the rich and civilized South. This role, however, required the existence of a strict binary system consisting of a nomadic political organism

225 Th.Cont., 122f.; DAI XLII (pp. 182, 184).Cf. Pletneva 1967, 3-5o, 44-46; Nagrodzka-Majchrzyk 1978, 131-134; Romashov 2004, 214-217; Ostrogorski 1967, 136, 162; Golden 1974, 62-63; 1980, 67f.; 1990, 265, 267.

226 Ostrogorski 1967, 136, 162; Vachkova 2008, 351-358.

227 Artamonov 1962, 400-424; Pletneva 1976, 61-71; Golden 199o, 268-269. 


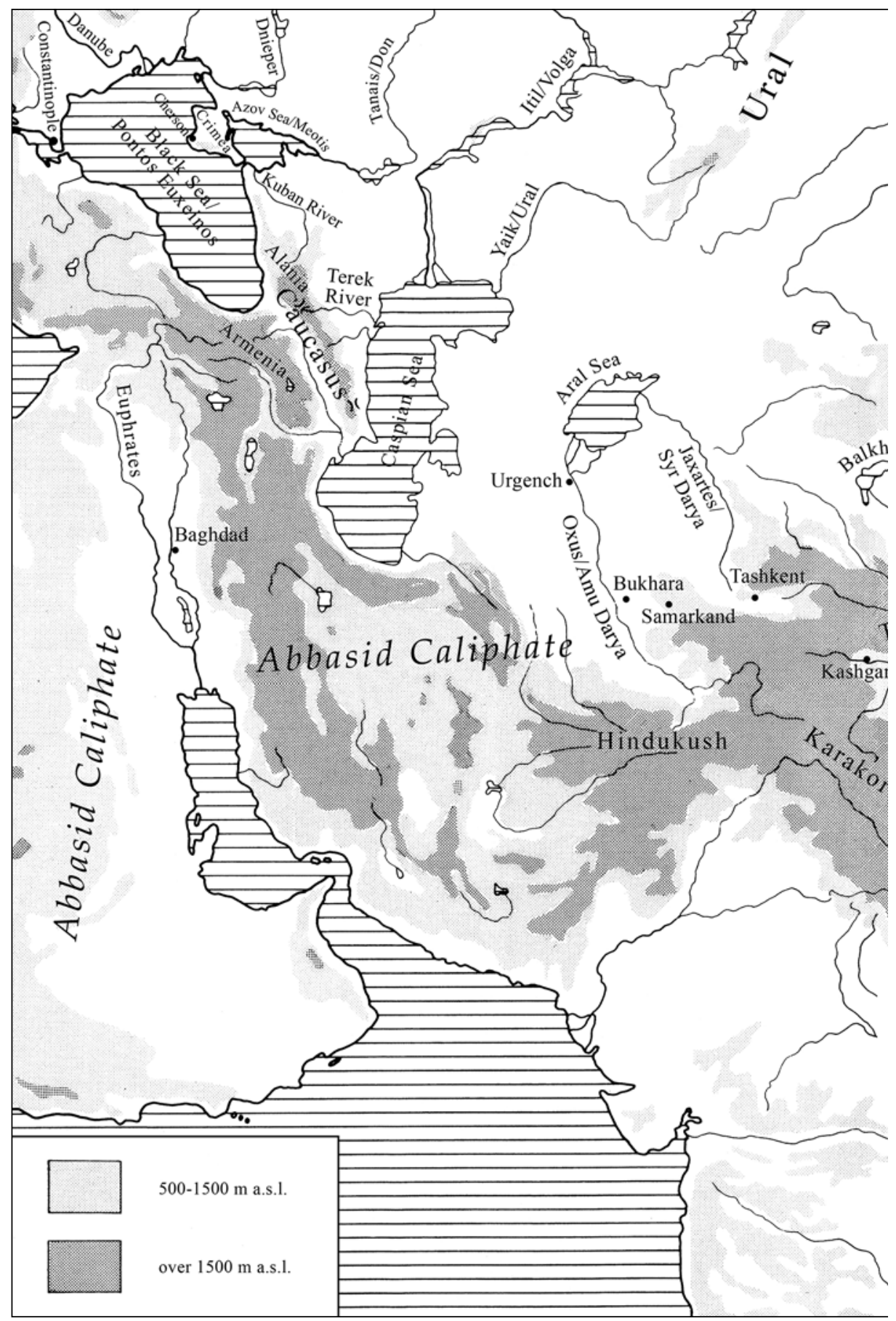

MAP 1 The Eurasian Steppe 


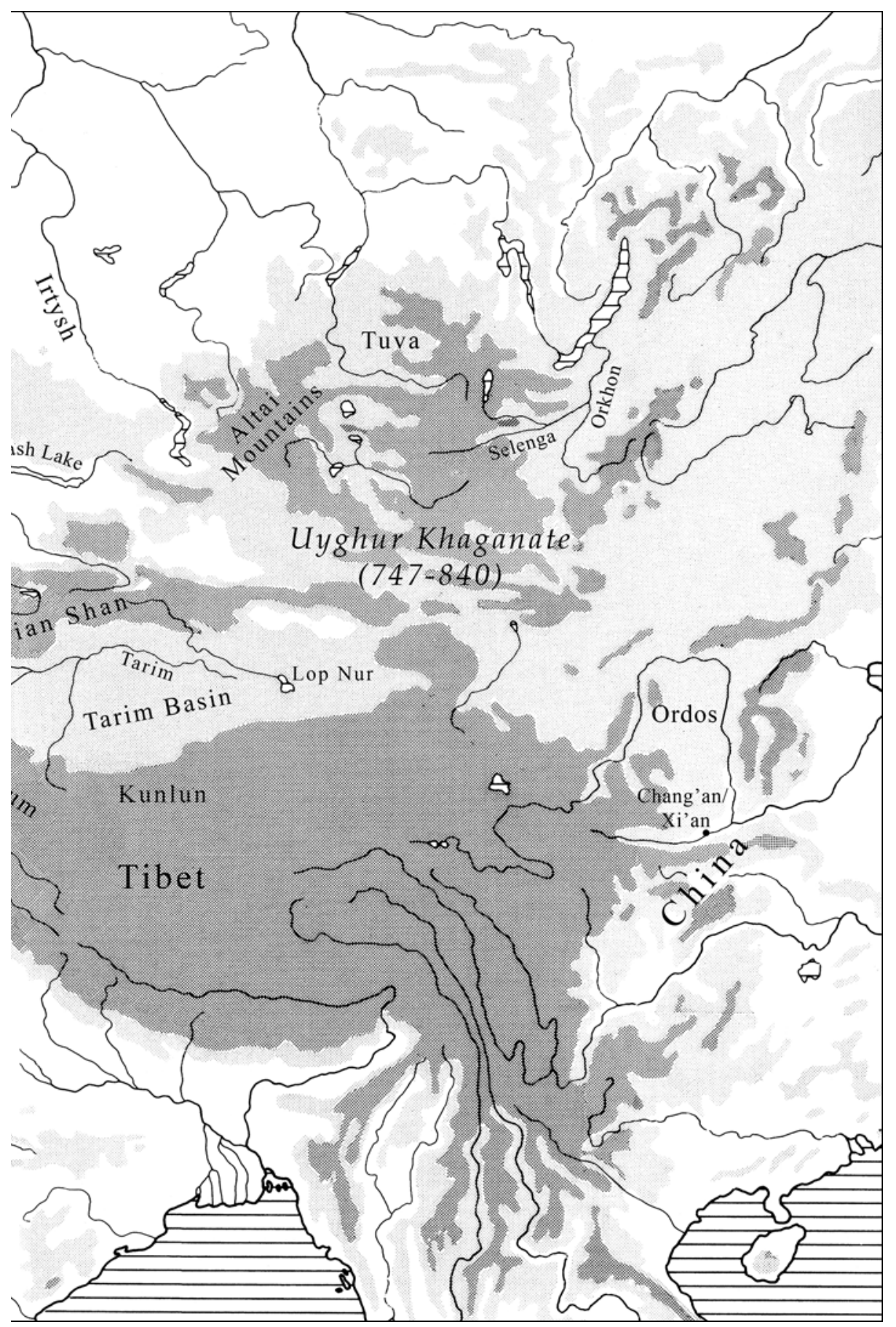


and its southern agricultural counterpart(s). If a strong political organism arose just outside the steppe zone, the presence of a nomadic intermediary could become a redundant feature, or even a hindrance, in North-South communication. In the light of these general observations, the case of the Eastern Goths, and especially the so-called Ermanaric state, is a very interesting one. A political structure of this kind presaged both the Pax Chazarica and, considering the origin of the Gothic elites, the 'Kievan Rus'. However, the Amali dynasty differed from the Rurikids in that the latter did not locate the centre of their state on the steppe. Perhaps it was this circumstance that made Ermanaric's kingdom less resistant to the attacks of the relatively uncivilized, but highly militarily effective Huns. The strength of the Huns' short-lived empire consisted in the creation of a perfect, albeit short-lived binary system linking the barbaric Hun North with the Roman South. Yet this relationship was overly exploitative, representing, in effect, a rationalized form of plunder. There was no room in it for the mutual benefits that result from the establishment of longdistance lines of communication. It would seem that the parasitic nature of Attila's plunder-based empire pre-determined its short-lived nature. The successes of the Scythians, Khazars, Huns and, to a lesser extent, Avars, in creating vast, early political organisms were far more spectacular. The other nomadic ethne that inhabited the Black Sea steppe functioned within much simpler political structures. The Pechenegs, due to both historical circumstances and their specific form of socio-political organization, will be closer to this latter group of nomadic peoples. 